\title{
Mass concentration, optical depth and carbon composition of particulate matter in the major southern West African cities of Cotonou (Benin) and Abidjan (Côte d'Ivoire)
}

\author{
Julien Djossou ${ }^{1}$, Jean-François Léon ${ }^{2}$, Aristide Barthélemy Akpo ${ }^{1}$, Cathy Liousse ${ }^{2}$, Véronique Yoboué $^{3}$, \\ Mouhamadou Bedou ${ }^{3}$, Marleine Bodjrenou ${ }^{1}$, Christelle Chiron $^{2}$, Corinne Galy-Lacaux $^{2}$, Eric Gardrat $^{2}$, \\ Marcellin Abbey ${ }^{1}$, Sékou Keita ${ }^{3}$, Julien Bahino ${ }^{3}$, Evelyne Touré N'Datchoh ${ }^{3}$, Money Ossohou ${ }^{3}$, and \\ Cossi Norbert Awanou ${ }^{1}$ \\ ${ }^{1}$ Laboratoire de physique du rayonnement, Université Abomey-Calavi, Abomey-Calavi, Bénin \\ ${ }^{2}$ Laboratoire d'Aérologie, Université Paul Sabatier Toulouse 3, CNRS, Toulouse, France \\ ${ }^{3}$ Laboratoire de Physique de l'Atmosphère, Université Felix Houphouet-Boigny, Abidjan, Côte d'Ivoire
}

Correspondence: Julien Djossou (jdjossou32@yahoo.fr)

Received: 19 October 2017 - Discussion started: 17 November 2017

Revised: 12 March 2018 - Accepted: 16 March 2018 - Published: 4 May 2018

\begin{abstract}
Air quality degradation is a major issue in the large conurbations on the shore of the Gulf of Guinea. We present for the first time $\mathrm{PM}_{2.5}$ time series collected in Cotonou, Benin, and Abidjan, Côte d'Ivoire, from February 2015 to March 2017. Measurements were performed in the vicinity of major combustion aerosol sources: Cotonou/traffic (CT), Abidjan/traffic (AT), Abidjan/landfill (AL) and Abidjan/domestic fires (ADF). We report the weekly $\mathrm{PM}_{2.5}$ mass and carbonaceous content as elemental (EC) and organic (OC) carbon concentrations. We also measure the aerosol optical depth (AOD) and the Angström exponent in both cities. The average $\mathrm{PM}_{2.5}$ mass concentrations were $32 \pm 32$, $32 \pm 24$ and $28 \pm 19 \mu \mathrm{g} \mathrm{m}^{-3}$ at traffic sites CT and AT and landfill site AL, respectively. The domestic fire site shows a concentration of $145 \pm 69 \mu \mathrm{g} \mathrm{m}^{-3}$ due to the contribution of smoking and roasting activities. The highest OC and EC concentrations were also measured at $\mathrm{ADF}$ at $71 \pm 29$ and $15 \pm 9 \mu \mathrm{g} \mathrm{m}^{-3}$, respectively, while the other sites present OC concentration between 8 and $12 \mu \mathrm{g} \mathrm{m}^{-3}$ and EC concentrations between 2 and $7 \mu \mathrm{g} \mathrm{m}^{-3}$. The OC / EC ratio is 4.3 at $\mathrm{CT}$ and 2.0 at AT. This difference highlights the influence of two-wheel vehicles using gasoline in Cotonou compared to that of four-wheel vehicles using diesel fuel in Abidjan. AOD was rather similar in both cities, with a mean value of 0.58 in Cotonou and of 0.68 in Abidjan. The seasonal cycle is dominated by the large increase in surface mass concentration and AOD during the long dry season (December-February)
\end{abstract}

as expected due to mineral dust advection and biomass burning activities. The lowest concentrations are observed during the short dry season (August-September) due to an increase in surface wind speed leading to a better ventilation. On the other hand, the high $\mathrm{PM}_{2.5}$ / AOD ratio in the short wet season (October-November) indicates the stagnation of local pollution.

\section{Introduction}

Many epidemiological studies have concluded that particulate pollution is directly related to serious human health risks such as respiratory tract infections, cardiovascular diseases and premature deaths (Dockery and Pope, 1994). This atmospheric pollution due to airborne fine particles is an environmental issue of increasing concern worldwide (Kacenelenbogen et al., 2006; West et al., 2016). The impact of this anthropogenic pollution has been the subject of numerous studies in Europe and North America, where emission reduction policies, in particular on combustion, are implemented. This is very different in West Africa. African cities are facing increasing air pollution problems. According to Liousse et al. (2014), Africa is an intense anthropogenic emitter (biomass fires, domestic fires, increasing car traffic, oil and mining industries increasing strongly). In con- 
junction with exceptional population growth on Earth, massive urbanisation and rapid economic growth: we are expecting a tripling of anthropogenic emission in Africa between 2000 and 2030. Particulate pollution in African megacities (e.g. Lagos in Nigeria, Johannesburg in South Africa) is expected to have strong implications for population health. According to Dieme et al. (2012) and Val et al. (2013), the aerosol particles in West African cities have strong implications for the population's health due to high aerosol concentration levels (Liousse and Galy-Lacaux, 2010), with inflammatory impacts directly linked to pollutant emission sources. Val et al. (2013) highlighted the high toxicity of fine particles in Bamako and Dakar, with a stronger impact than in European cities such as Paris.

Carbonaceous aerosols are one of the major components of fine particulate matter $\left(\mathrm{PM}_{2.5}\right)$ in urbanised areas as a result of combustion emissions (Zhang et al., 2007). Carbonaceous matter is usually classified into organic carbon (OC) and elemental carbon (EC). Elemental carbon is a primary pollutant emitted from combustion sources and does not undergo chemical transformations, while OC can be either released directly into the atmosphere from combustion and biogenic sources or formed within the atmosphere through gasto-particle conversion of volatile organic compounds through photochemical reactions (Cao et al., 2003; Turpin and Huntzicker, 1995). At the global scale, the most recent estimates for the year 2000 (Lamarque et al., 2010) have shown that anthropogenic combustions and biomass burning roughly generate about 65 and $35 \%$ of EC emissions, respectively, and 35 and $65 \%$ of primary OC emissions. OC and EC not only contribute to the overall $\mathrm{PM}_{2.5}$ load, but these components also have specific public health concerns because of their interactions with the human body (Dou et al., 2015; Shi et al., 2015).

Carbonaceous aerosols in West Africa are known to result from biomass burning, traffic and domestic fire emissions and to a lesser extent from other combustion sources such as industries, power plants and flaring (Doumbia et al., 2012; Liousse et al., 1996, 2014; Liousse and Galy-Lacaux, 2010). According to Liousse et al. (1996, 2010), the emissions from biomass burning have importance for the atmospheric composition in rural West Africa. Atmospheric aerosol in West African rural areas and typical inter-tropical ecosystems has been the subject of research programs such as DECAFE (Cachier et al., 1995; Lacaux et al., 1995), IDAF (GalyLacaux et al., 2009) and EXPRESSO (Delmas et al., 1999). The DECAFE program allowed us to characterise the chemical composition of aerosols during savanna fires in West Africa (Côte d'Ivoire). However, very little information exists on aerosols in West African cities.

In the cities of sub-Saharan Africa such as Cotonou (Benin), the emissions from two-wheeled vehicles running on mixtures of gasoline smuggled from Nigeria and motor oil are a large source of pollutants (Liousse et al., 2014). The atmosphere in the city of Cotonou is characterised by thick opaque fumes, especially at main highways and intersections (Mama et al., 2013). This phenomenon is linked to the use of two-wheeled motorcycles, especially the motorcycle taxi called zémidjan; the number of these in 2005 was estimated at 96095 according to the statistics of Cotonou City Council (Ayi Fanou et al., 2006; Mama et al., 2013). In Cotonou motorbike taxis account for $90 \%$ of cases of intoxication symptoms; this is 1.5 times higher than in non-drivers of these motorbikes. The symptoms recorded are intoxication disorders such as conjunctival hyperemia (18\%), among which $12 \%$ are made up by lacrimation, and respiratory disorders (23\%) (Fourn and Fayomi, 2006). According to Fourn and Fayomi, (2006) and Mama et al. (2013), motorcycle taxi emissions are the highest in the Dantokpa area.

The results obtained by Doumbia et al. (2012) confirm that in West and sub-Saharan African big cities there is a "hot spot" of emissions, particularly due to the emissions from vehicle engines and domestic fires. Nevertheless, pollution in urban African areas and their related health impacts have been poorly studied. Therefore, observations for fineparticle $\left(\mathrm{PM}_{2.5}\right)$ and particulate carbon species are needed for African cities.

Note that such pollution linked to domestic fires, traffic or waste burning should occur throughout the year whereas transported biomass burning and Saharan dust are expected to have an impact during the dry seasons around December and January (Doumbia et al., 2012; Liousse et al., 2010, 2004).

The Dynamic Aerosol-Cloud-Chemistry Interaction in West Africa (DACCIWA) research program started in 2014 (Knippertz et al., 2015). One of the aims of the program is to characterise the health impact of atmospheric pollution on SWA (southern West Africa) populations. An enhanced observation period (EOP) for assessing $\mathrm{PM}_{2.5}$ mass concentration and particulate carbon species was conducted from February 2015 to March 2017 in two coastal cities representative of SWA conurbations: Abidjan in Côte d'Ivoire and Cotonou in Benin. Three sites have been chosen in Abidjan with a focus on specific sources: domestic fires due to smoking activity, traffic at a crossroads and waste burning at the landfill. The traffic in Abidjan is dominated by cars and buses, while in Cotonou it is dominated by two-wheel vehicles (Ayi Fanou et al., 2006; Assamoi and Liousse, 2010; Mama et al., 2013). For this reason, an additional traffic site has been selected in Cotonou.

In addition to measuring $\mathrm{PM}_{2.5}$ and carbonaceous species, the field experiment was also designed to acquire observations of the spectral aerosol optical depth (AOD). Indeed AOD is an indicator of the aerosol load in the atmospheric column and its spectral behaviour provides information on the shape of the aerosol size distribution (O'Neill et al., 2003) and so the aerosol type. The AOD in the Sahel region has been largely investigated (Horowitz et al., 2017; Léon et al., 2009; Mallet et al., 2008) thanks to the availability of the AERONET automatic sun photometer (Holben et al., 1998). 


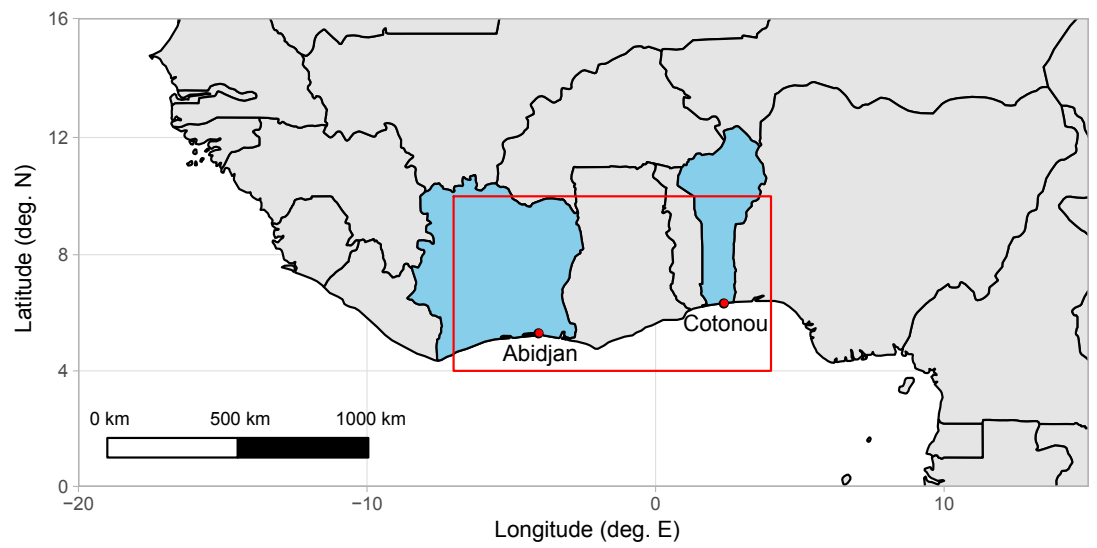

Figure 1. Geographical locations of Abidjan and Cotonou cities. The red rectangle corresponds to the geographical area between $7^{\circ} \mathrm{W}-4^{\circ} \mathrm{E}$ and $4-10^{\circ} \mathrm{N}$ (see Fig. 9).

Horowitz et al. (2017) have suggested that biomass burning aerosol could make up a large fraction of the AOD in SWA during the burning season (December-February) from observations recorded in northern Benin (Djougou) and Nigeria (Ilorin). However, the coastal urban zone of SWA clearly lacks dedicated observations, which can in turn be used to understand local $\mathrm{PM}_{2.5}$ variations better.

This paper focuses on fine-particle mass, particulate carbon species and aerosol optical depth measurements performed over these four sites. Weekly-averaged data will be first presented, followed by seasonal variation analysis. Then the discussion will deal with a comparison with worldwide measurements. This paper is the first contribution to aerosol source identification within the two cities.

\section{Methods}

\subsection{Site locations}

Our experimental strategy is based on sampling the polluted atmosphere of different source environments in the two major southwestern African cities of Abidjan in Côte d'Ivoire and Cotonou in Benin from February 2015 to March 2017. Figure 1 gives the geographical position of both cities in SWA.

Abidjan $\left(5^{\circ} 20^{\prime} \mathrm{N}, 4^{\circ} 1^{\prime} \mathrm{W}\right)$ is the most important economical city in Côte d'Ivoire. It had 6.5 million inhabitants in 2016. Similarly, Cotonou $\left(6^{\circ} 21^{\prime} \mathrm{N}, 2^{\circ} 26^{\prime} \mathrm{E}\right)$ is the most important economical city of Benin. It had about 1.5 million inhabitants in 2016. Both cities have a subequatorial climate characterised by two dry and two wet seasons. The long rainy season extends from April to July and the short rainy season from October to November (Ernest et al., 2013). These two seasons are interspersed with two dry periods that extend from December to March and from August to September (Djossou et al., 2017; Dossou and Glehouenou-Dossou, 2007; Ernest et al., 2013). The long rainy season is dom- inated by the West African monsoon (Sultan and Janicot, 2003), corresponding to the southwestern prevailing winds advecting humidity and precipitation to the continent. The long dry season from December to March is dominated by the northeasterly Harmattan wind (Sauvage et al., 2005), carrying mineral dust emitted from arid areas (Adetunji et al., 1979).

Figure 2 gives the geographical location of each site within the respective cities. In Cotonou (hereinafter called CT), one site representative of traffic emission has been investigated.

The CT site in Cotonou is located in the Dantokpa area, one of the biggest markets in western Africa. The instrument is located on a balcony at $4 \mathrm{~m}$ height above a major crossroads. As shown in Fig. 4a the traffic at the crossroads is largely dominated by two-wheel vehicles including zémidjan.

In Abidjan, we set up the instrumentation at three sites representative of traffic (hereinafter called AT), waste burning at landfill (AL) and domestic fires (ADF) emissions. ADF is located in the market of Yopougon-Lubafrique $\left(5^{\circ} 19.746^{\prime} \mathrm{N}\right.$, $4^{\circ} 6.353^{\prime} \mathrm{W}$ ) in a large courtyard with about 25 fireplaces (Fig. 4d). Fireplaces are active from 06:00 to 15:00 UTC. The highest activity is between 06:00 and 10:00 UTC The smoke is due to smoking meat and fish or roasting peanuts. The instrumentation is set up on a $3 \mathrm{~m}$ height tower. The fuel used is essentially hevea wood stored outside in the vicinity of the fireplaces. AT is located at Adjamé bus station $\left(5^{\circ} 21.252^{\prime} \mathrm{N}\right.$, $4^{\circ} 1.095^{\prime} \mathrm{W}$ ) and more precisely on the roof of the pharmacy 220 logements. Adjamé bus station is one of the major traffic areas for small buses, called baka, in Abidjan, and so this area is largely influenced by four-wheel vehicle emissions as shown in Fig 4b. The traffic is dominated by old vehicles (four wheels) using diesel. AL is near the public landfill of Akouédo $\left(5^{\circ} 21.215^{\prime} \mathrm{N}, 3^{\circ} 56.277^{\prime} \mathrm{W}\right)$ on the flagstone roof a three-storey building at about $12 \mathrm{~m}$ above ground. The public dump has received all of the waste produced in the district of Abidjan for the last 50 years; it currently receives more 
(a)

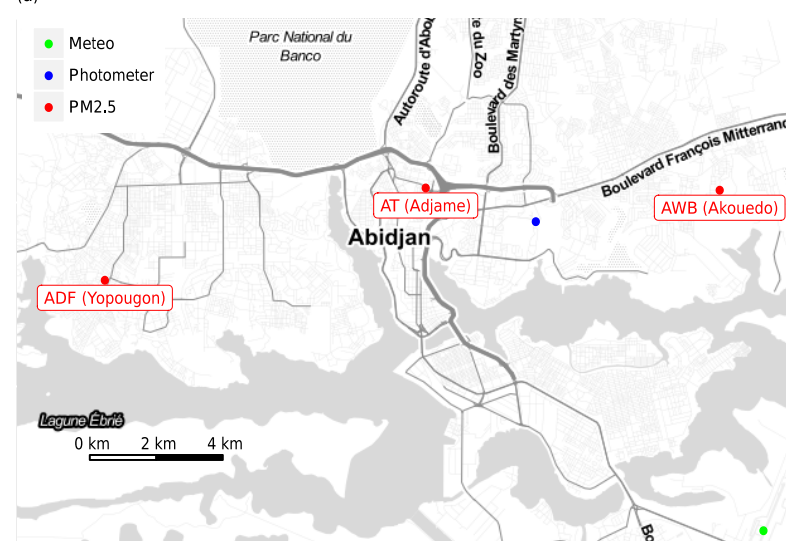

(b)

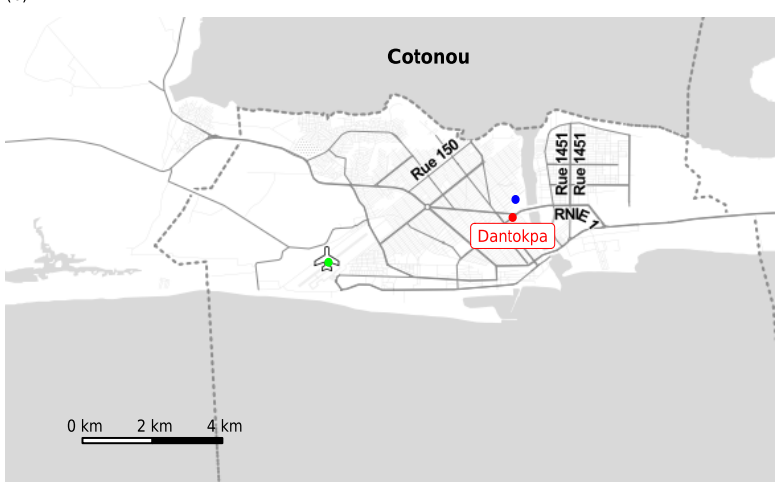

Figure 2. Maps of the cities of (a) Abidjan and (b) Cotonou reporting the location of the (red) $\mathrm{PM}_{2.5}$ sampling sites, (blue) photometer measurements and (green) meteorological station.

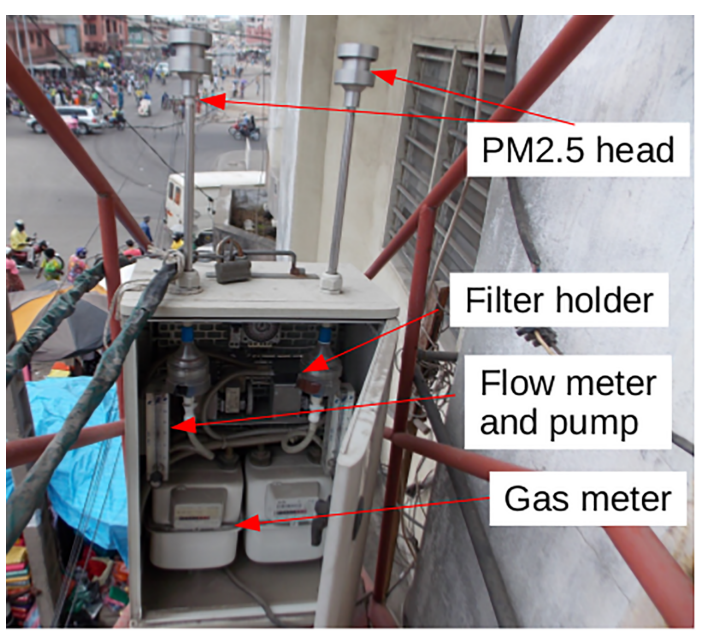

Figure 3. Picture of the sampling box standing outside at the CT site and showing the elements of the sampling lines.

than $1000000 \mathrm{t}$ of waste a year (Adjiri et al., 2015). It negatively affects the environment and the living environment of the populations of Abidjan in general (UNEP, 2015). Dump workers burn waste mainly during the dry season. Spontaneous ignition also occurs in the landfill during the dry season. Figure $4 \mathrm{~d}$ shows a combustion plume rising from the dump as seen from our sampling site.

\subsection{Sampling}

The particles were collected on $47 \mathrm{~mm}$ diameter filters on a weekly basis. Two types of filters are used depending on the analysis performed. PTFE filters were used for gravimetric measurements while quartz fibre filters were used for carbonaceous aerosol analysis. The use of different types of filter requires the set-up of two filtration lines operating in parallel. The sampling system uses two mini Partisol sam- pling impactors for $\mathrm{PM}_{2.5}$ working at a flow of $5 \mathrm{~L} \mathrm{~min}^{-1}$. Both lines are stored in the same box standing outside at ambient temperature and humidity. Figure 3 provides a quick view of the inside of the sampling box, which is equipped for each line with a KNF pump with a flow rate of $9 \mathrm{~L} \mathrm{~min}^{-1}$ (N89 KNE-K version 220v), a Cole Palmer ball flow meter with a micrometric valve (flow range adjustable from 0 to $10 \mathrm{Lmin}^{-1}$, accuracy $5 \%$ ), a GALLUS-type G4 gas meter (accuracy of $0.01 \mathrm{~m}^{-3}$ ) giving the total volume of air sampled during the week, tubing, and a NILU online filter holder (see also Ouafo-Leumbe et al., 2017).

The concentrations of $\mathrm{PM}_{2.5}$ particles and carbonaceous aerosols (OC and EC) have been measured at a weekly time step by the ambient air pumping technique over a 2-year period (February 2015-March 2017) for the four sites mentioned above. The air is sampled for $15 \mathrm{~min}$ every hour, leading to a total volume of sampled air of about $12.6 \mathrm{~m}^{3}$ by week. Due to power failure, some weeks were not sampled. The filters are stored in packs before sampling and then individually in Petri dishes and covered with aluminium foil once the sample has been collected. They are then returned to Toulouse, France, for analysis at the Laboratoire d'Aérologie.

Additionally, the AOD was measured in central Cotonou and Abidjan every day using a lightweight handheld sun photometer recording the solar irradiance at 465,540 and $619 \mathrm{~nm}$. The operators performed the measurement at around 13:00 UTC. The analysis of the log file of the sun photometer shows actual measurements between 11:00 and 14:00 UTC. Using AERONET observations, Smirnov et al. (2002) give a diurnal variability between 10 and $40 \%$, with an increase during daytime and showing that the measurements which were acquired at noon are within $5-10 \%$ of the daily average. So the diurnal cycle of the AOD is expected to be low, and those measurements are considered to be representative of the daily mean AOD hereinafter. 


\subsection{Gravimetric analysis}

PTFE filters were weighed before and after sampling using a high-precision scale (SARTORIUS MC21S) in Toulouse, France, at Laboratoire d'Aérologie. Before weighing, the samples were kept for about $24 \mathrm{~h}$ in the weighing room at an ambient relative humidity of $30 \pm 15 \%$.

\subsection{Carbonaceous aerosols}

Carbonaceous aerosols OC, EC and total carbon (TC, calculated by the sum of OC and EC) were measured on a $0.55 \mathrm{~cm}^{2}$ punch from each quartz filter by thermo-optical reflectance following the Interagency Monitoring of Protected Visual Environments (IMPROVE) protocol (Chiappini et al., 2013; Ouafo-Leumbe et al., 2017). The quartz fibre filters are burned $48 \mathrm{~h}$ at $480^{\circ} \mathrm{C}$ before sampling to reduce the carbon content on the blank filter (filter blanks about $0.8 \mu \mathrm{gC}$ for $\mathrm{OC}$ and $0.2 \mu \mathrm{gC}$ for EC). The analyses are performed using a DRI model 2001 thermal/optical carbon analyser (Atmoslytic Inc., Calabasas, CA) (Chow et al., 1993, 1994, 2004, 2006). In pure helium (He) atmosphere, OC fractions are obtained in the four first stages of temperature $(\mathrm{OC} 1$, $\mathrm{OC} 2, \mathrm{OC} 3$ and $\mathrm{OC} 4$ at $120,250,450$ and $550^{\circ} \mathrm{C}$, respectively). After pyrolysis, $2 \%$ additional oxygen is added to $98 \%$ inert $\mathrm{He}$, and $\mathrm{EC}$ fractions are obtained from three temperature steps $\left(\mathrm{EC} 1, \mathrm{EC} 2\right.$ and $\mathrm{EC} 3$ at 550,700 and $800^{\circ} \mathrm{C}$, respectively). The sum of $\mathrm{OC}$ fractions added to the pyrolysed carbon fraction (OP) gives the concentration of OC in the sample, whereas EC concentration is the difference between sum of EC fractions and OP. The detection limit estimated by the DRI analyser based on the instrument blank is 0.4, 0.1 and $0.3 \mu \mathrm{g} \mathrm{Cm}^{-2}$ for TC, EC and OC. The accuracy estimated from our measurements is $5 \%$ for TC and $10 \%$ for EC and OC.

\subsection{Sun photometer}

A handheld sun photometer is a well-known scientific instrument for measuring atmospheric transmission (Porter et al., 2001; Volz, 1959, 1974). In this study, we used a lightweight handheld sun photometer manufactured by TENUM (http: //www.calitoo.fr, last access: 24 April 2018). The sun photometer measures the Sun's irradiance at three wavelengths $(465,540$ and $619 \mathrm{~nm})$. The atmospheric optical depth is retrieved following the Beer-Lambert law knowing the calibration constant for each instrument and the relative air mass. Sun photometers are calibrated prior to site deployment using the Langley-plot method (Schmid and Wehrli, 1995; Soufflet et al., 1992). The AOD is then retrieved after subtracting the Rayleigh and trace gases optical depth.

Measurements are performed only for a cloud-free field of view. The operators were asked to take measurements only when the sun was not obscured by clouds and carried out with a sequence of five measurements within about
$10 \mathrm{~min}$. The presence of sub-visible cirrus or broken clouds within the field of view induces spurious variation in the atmospheric transmission (Smirnov et al., 2000) that can be easily detected by looking at the SD of the small series of AOD measurements. An arbitrary threshold of 0.2 on the SD has been selected to remove the cloud-contaminated observations. The Ångström exponent (Ångström, 1961) is computed between wavelengths 465 and $540 \mathrm{~nm}$. AOD measurements are reported at $550 \mathrm{~nm}$ because this wavelength is a reference for visibility calculation (Boers et al., 2015) and satellite mission (e.g. Remer et al., 2008). For the sake of consistency with PM measurements, the daily AODs are then averaged on a weekly basis.

\subsection{Ancillary data}

We have used the meteorological observations provided by the NOAA Integrated Surface database (ISD; see https:// www.ncdc.noaa.gov/isd, last access: 24 April 2018, for more details) for both cities. Data are local measurements recorded at the airports of each cities, namely Cardinal Bernadin Gantin International Airport and Felix Houphouet Boigny Airport. We used the daily data giving the rainfall, air temperature and wind. Figure 2 gives the precise location of the meteorological stations for each city.

A secondary set of ancillary data is the daily burnt surface area given by the MCD64A1 satellite product derived from MODIS on Aqua and Terra (Roy et al., 2008; Roy and Boschetti, 2009). The burnt surface area provides a proxy for the intensity and the time occurrence of biomass burning emissions. The spatial resolution is $500 \mathrm{~m}$. The data were accessed from the Land Processes Distributed Active Archive Center (LP DAAC). From those data, we have computed the weekly burnt surface in the area presented in Fig. 1, from $7^{\circ} \mathrm{W}$ to $4^{\circ} \mathrm{E}$ and 4 to $10^{\circ} \mathrm{N}$, located north of our sites.

\section{Results}

\subsection{Mass and carbon concentrations}

Figure 5 shows the time series of weekly $\mathrm{PM}_{2.5}$ along with the OC, EC and TC mass concentrations obtained at the four different sites for the 2-year period. The $\mathrm{PM}_{2.5}$ concentrations at the three "urban-like" sites CT, AT and AL do indeed present a very similar time behaviour. Large spikes above $100 \mu \mathrm{g} \mathrm{m}^{-3}$ between December and April characterise the time series. The main feature of the ADF $\mathrm{PM}_{2.5}$ time series is totally different, showing a bell shape in the annual cycle with maxima during July-August.

$\mathrm{PM}_{2.5}$ varies from 11 to $174 \mu \mathrm{g} \mathrm{m}^{-3}$ at AT, 8 to $226 \mu \mathrm{g} \mathrm{m}^{-3}$ at CT, 7 to $112 \mu \mathrm{g} \mathrm{m}^{-3}$ at AL and 18 to $436 \mu \mathrm{g} \mathrm{m}^{-3}$ at ADF. At AT, CT and AL sites, higher weekly concentrations were observed in dry seasons and lower one in the wet season. We found that the average $\mathrm{PM}_{2.5}$ mass concentrations at $\mathrm{CT}$, $\mathrm{AT}$ and $\mathrm{AL}$ are similar. The mean weekly $\mathrm{PM}_{2.5}$ mass con- 
(a)

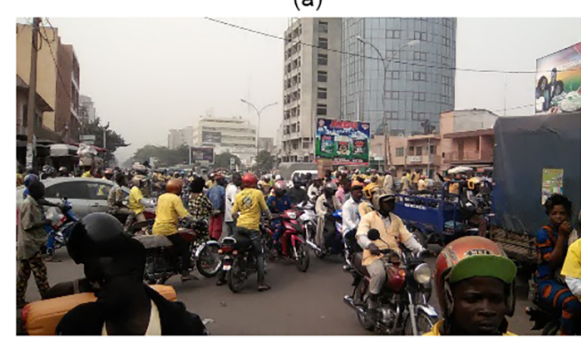

(c)

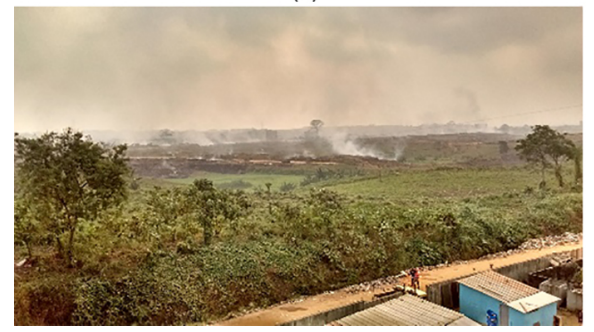

(b)

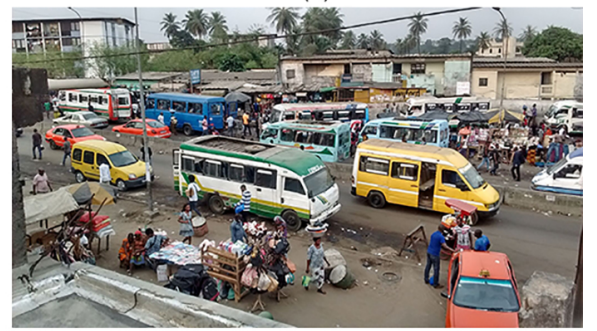

(d)

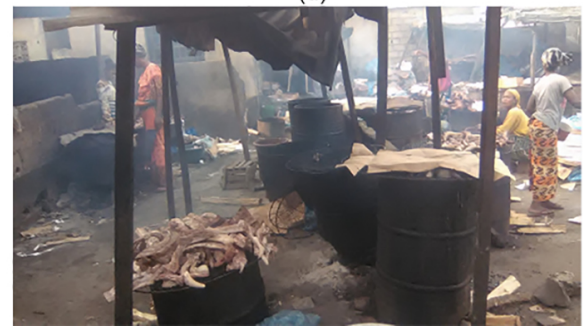

Figure 4. Pictures showing the immediate environment of the stations: (a) two-wheel traffic in Cotonou (CT station), (b) small-bus traffic in Abidjan (AT station), (c) waste burning at the Abidjan landfill (AL station), (d) smoking activity in Abidjan-Yopougon (ADF station).

centration is $32 \pm 32 \mu \mathrm{g} \mathrm{m}^{-3}$ at $\mathrm{CT}, 32 \pm 24 \mu \mathrm{g} \mathrm{m}^{-3}$ at AT and $28 \pm 19 \mu \mathrm{g} \mathrm{m}^{-3}$ at AL. However, it is $145 \pm 69 \mu \mathrm{g} \mathrm{m}^{-3}$ at ADF, clearly highlighting the strong impact of nearby smoking activity. For comparison, the World Health Organization recommends a threshold value of $10 \mu \mathrm{g} \mathrm{m}^{-3}$ as a guideline for annual $\mathrm{PM}_{2.5}$. On average, AL remains at the same level as the traffic sites $\mathrm{CT}$ and $\mathrm{AT}$, showing that the waste burning activities probably did not affect our sampling as much as expected because the site was not located exactly downwind of the dump.

The time series of carbonaceous components shows a similar behaviour to the $\mathrm{PM}_{2.5}$, with a seasonal variability and sporadic spikes (discussed in the next section). As a consequence of the vicinity of ADF to emission sources, the TC content is higher than at the other sites. TC is at $86 \mu \mathrm{g} \mathrm{m}^{-3}$ $( \pm 35)$ at $\mathrm{ADF}$, while it is $19 \mu \mathrm{g} \mathrm{m}^{-3}( \pm 12)$ at $\mathrm{AT}, 10 \mu \mathrm{g} \mathrm{m}^{-3}$ $( \pm 7)$ at $\mathrm{CT}$ and $14 \mu \mathrm{g} \mathrm{m}^{-3}( \pm 8)$ at $\mathrm{AL}$.

The $\mathrm{OC} / \mathrm{EC}$ ratio in Abidjan is 2.0 at $\mathrm{AT}$ and 3.3 at $\mathrm{AL}$ (see Fig. 8, discussed later in the text). However, it is 4.3 in Cotonou. This difference could be expected since Cotonou traffic emissions are dominated by two-wheel vehicles with two-stroke engines that use a mix of different motor oils. The highest OC / EC ratio of 5.3 is observed at ADF in relation to biomass combustion for fish and meat smoking.

\subsection{Seasonal variations}

\subsection{1 $\quad \mathbf{P M}_{2.5}$}

Hereinafter, we have separated the 2-year period into eight seasons: two long dry seasons labelled D1 (December 2015-March 2016) and D2 (December 2016March 2017), two long wet seasons labelled W1 (AprilJuly 2015) and W2 (April-July 2016), two short dry seasons labelled D1' (August-September 2015) and D2' (August-September 2016), and two short wet seasons labelled W1' (October-November 2015) and W2' (OctoberNovember 2016). Figure 6 reports the weekly average rainfall rate and temperature for both Cotonou and Abidjan. For both cities, the weekly mean air temperature is between 25 and $30^{\circ} \mathrm{C}$, reaching a minimum during the short dry season $\left(\mathrm{D} 1^{\prime}\right.$ and $\left.\mathrm{D} 2^{\prime}\right)$. The precipitation pattern is also similar for both cities although Abidjan receives more rain than Cotonou in W1. Yearly and seasonal average meteorological parameters are reported in Table 1.

Table 2 gives the seasonal average of $\mathrm{PM}_{2.5}$ concentrations and carbonaceous matter (OC and EC), considering both the first and the second year. The three urban sites (CT, AT and $\mathrm{AL}$ ) show similar seasonal variation, as expected from Fig. 5. The maximum average concentrations of $\mathrm{PM}_{2.5}$ are measured during the long dry season $\mathrm{D}$ at about $50 \mu \mathrm{g} \mathrm{m}^{-3}$. The minimum $\mathrm{PM}_{2.5}$ concentrations are observed during the short dry season $\left(\mathrm{D}^{\prime}\right)$ for all the three sites around $18 \mu \mathrm{g} \mathrm{m}^{-3}$. The average $\mathrm{PM}_{2.5}$ concentration is always higher during $\mathrm{W}^{\prime}$ than $\mathrm{W}$. A decrease in the $\mathrm{PM}_{2.5}$ concentration is expected due to wet scavenging as the precipitation rate in both cities is much higher during $\mathrm{W}$ than during $\mathrm{W}^{\prime}$.

The highest average concentrations of $\mathrm{PM}_{2.5}$ at $\mathrm{ADF}$ are measured during $\mathrm{D}^{\prime}$. $\mathrm{PM}_{2.5}$ also remains high during $\mathrm{W}^{\prime}$ and $\mathrm{W}$. At least three factors may explain the high concentration during $\mathrm{W}, \mathrm{W}^{\prime}$ and $\mathrm{D}^{\prime}$ in ADF: (i) an increase in smoking activity, (ii) a change in fuel (wood) or (iii) a change in combustion due to the moisture content of the wood. The emission factor (EF) for $\mathrm{PM}_{2.5}$ and carbonaceous species depends on fuel type and combustion. Keita et al. (2017) give a factor of 2 between EF and hard and soft wood. Moreover Shen et al. (2013) show that EF for PM and OC can be a factor 
(a)
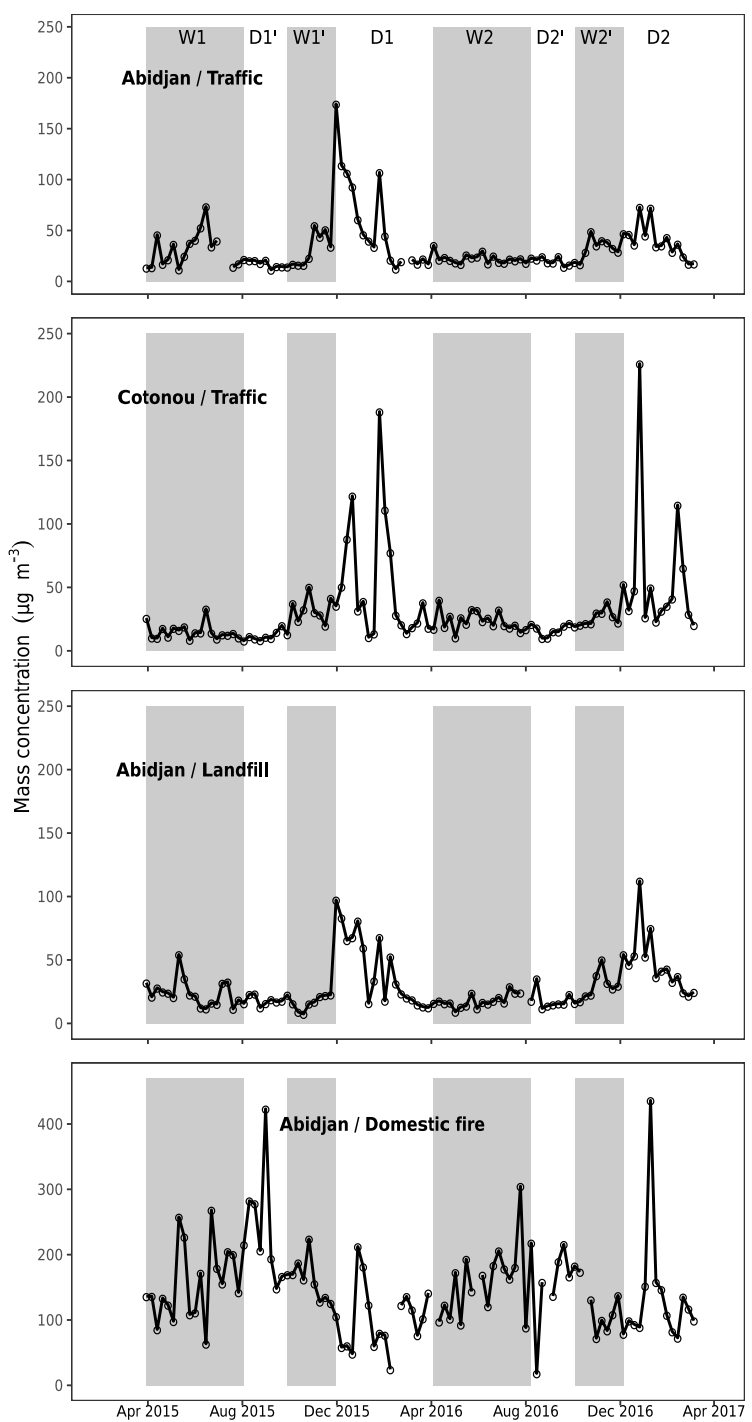

(b) $\rightarrow \mathrm{EC}=\mathrm{OC} \rightarrow \mathrm{TC}$
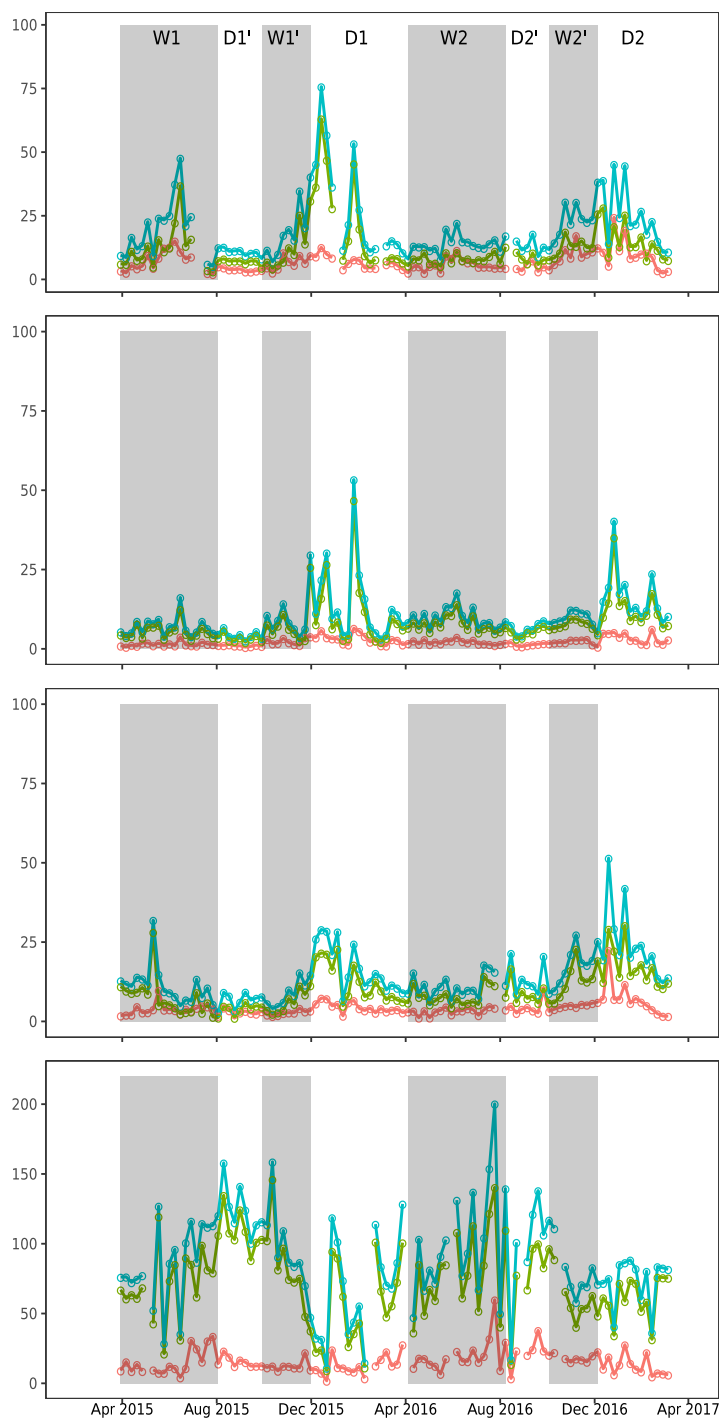

Figure 5. Time series of (a) $\mathrm{PM}_{2.5}$ in $\mu \mathrm{g} \mathrm{m}^{-3}$ and (b) carbonaceous weekly concentrations in $\mu \mathrm{g} \mathrm{Cm}{ }^{-3}$ at the four sites from April 2015 to March 2017. Shaded areas show the different seasons (see text): the long rainy seasons W1 and W2; the short dry seasons D1' and D2'; the short rainy seasons $\mathrm{W}^{\prime}{ }^{\prime}$ and $\mathrm{W}^{\prime}$; and the long dry seasons D1 and D2.

of 2 higher for humid wood, which can be the case during season $\mathrm{W}, \mathrm{W}^{\prime}$ and $\mathrm{D}^{\prime}$ as wood is stored outside. We cannot actually verify those hypotheses as we did not monitor smoking activity, fuel type and humidity during the experimental period.

\subsubsection{AOD}

The contribution of advected mineral dust and biomass burning aerosol by northerly winds is also high during the dry season (Balarabe et al., 2016). Following Kaufman et al. (2000), large particles (dust or maritime aerosols) are dominant in the size distribution when the Ångström coefficient is below 0.7, although Toledano et al. (2007) have reported a threshold of 1.05. A low value, typically below 0.8 , of the Angström exponent associated with high AOD, typically above 0.6 (Verma et al., 2015), indicates a significant contribution of coarse dust-like particles to the AOD (Balarabe et al., 2016).

The presence of dust over the cities during the long dry season can be inferred by looking at the AOD and Ångström exponent in Fig. 7, which presents the weekly AOD measurements obtained from daily measurements in Abidjan and Cotonou. The range of weekly AOD in Cotonou is [0.121.93] with an average value of 0.63 , while in Abidjan, the range is [0.16-1.18] and the average is 0.56 . The seasonal pattern is very similar to both cities with a pronounced increase during the long dry seasons, although Cotonou shows a higher AOD than Abidjan. The Ångström exponent follows 


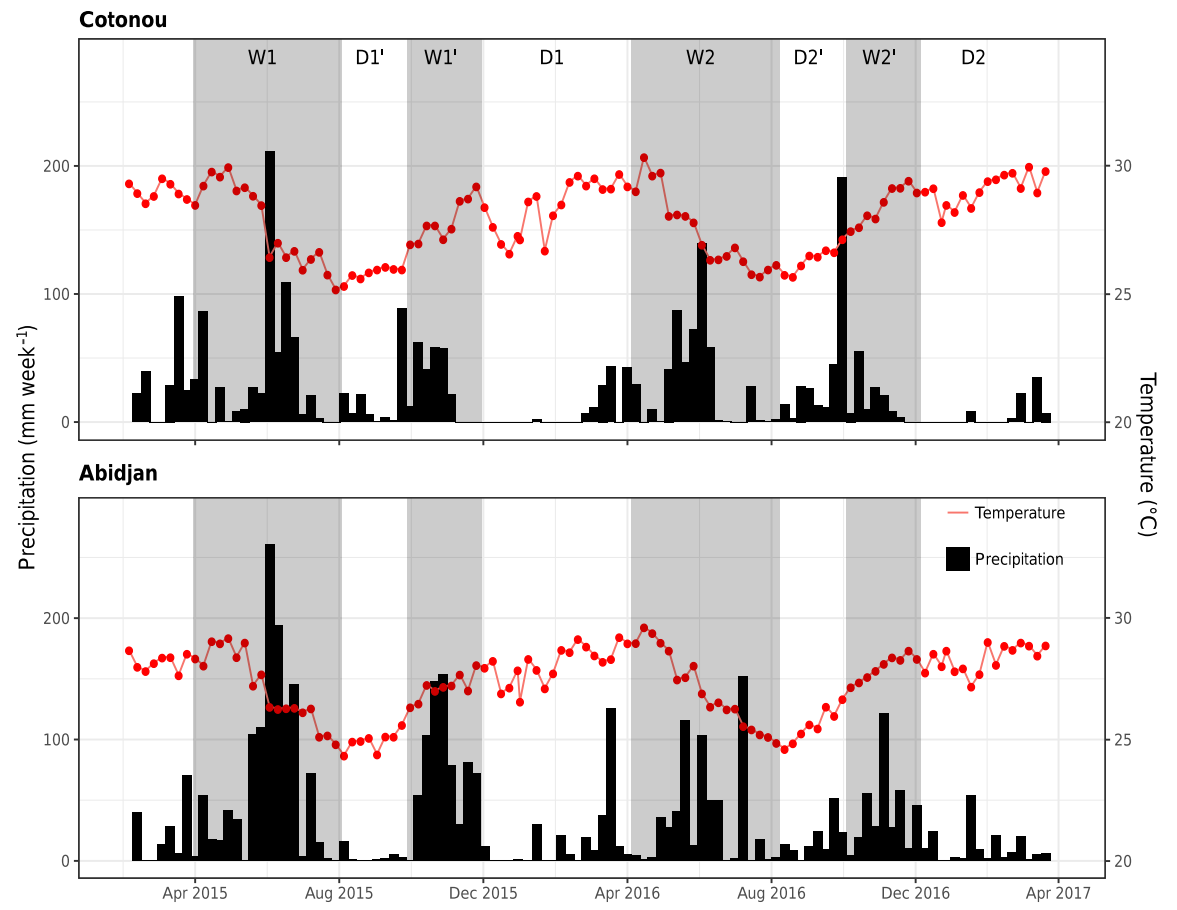

Figure 6. Weekly precipitation rate and mean temperature for Cotonou and Abidjan from February 2015 to March 2017 . W1 and W2, the long rainy seasons; $\mathrm{D} 1^{\prime}$ and $\mathrm{D} 2^{\prime}$, the short dry seasons; $\mathrm{W} 1^{\prime}$ and $\mathrm{W} 2^{\prime}$; the short rainy seasons; and D1 and D2, the long dry seasons for all the study period.

Table 1. Seasonal average of precipitations, wind speed, aerosol optical depth (AOD) and Ångström exponent for Abidjan and Cotonou sites. $\mathrm{W}$ and $\mathrm{W}^{\prime}$ are the long and short rainy seasons and $\mathrm{D}$ and $\mathrm{D}^{\prime}$ are the long and short dry seasons, respectively.

\begin{tabular}{|c|c|c|c|c|c|c|}
\hline City & Season & $\begin{array}{l}\text { Number of days } \\
\text { in each season }\end{array}$ & $\begin{array}{r}\text { Precipitation } \\
\mathrm{P}(\mathrm{mm})\end{array}$ & $\begin{array}{l}\left(\mathrm{ms}^{-1}\right) \\
\left(\mathrm{ms}^{-1}\right)\end{array}$ & $\mathrm{AOD}_{550 \mathrm{~nm}}$ & $\alpha_{465-619}$ \\
\hline \multirow[t]{7}{*}{ Abidjan } & W & 122 & 911 & 3.4 & $0.5 \pm 0.2$ & $0.7 \pm 0.3$ \\
\hline & $\mathrm{D}^{\prime}$ & 61 & 75 & 3.5 & $0.3 \pm 0.1$ & $1.1 \pm 0.2$ \\
\hline & $\mathrm{W}^{\prime}$ & 61 & 332 & 3.2 & $0.3 \pm 0.1$ & $1.2 \pm 0.2$ \\
\hline & $\mathrm{D}$ & 121 & 244 & 2.9 & $0.7 \pm 0.2$ & $0.8 \pm 0.2$ \\
\hline & Year 1 & & 2214 & 3.3 & $0.5 \pm 0.3$ & $0.9 \pm 0.3$ \\
\hline & Year 2 & & 1312 & 3.2 & $0.5 \pm 0.2$ & $0.9 \pm 0.2$ \\
\hline & Total & & 5780 & 3.2 & $0.6 \pm 0.2$ & $0.9 \pm 0.3$ \\
\hline \multirow[t]{7}{*}{ Cotonou } & W & & 607 & 4.3 & $0.5 \pm 0.2$ & $0.8 \pm 0.4$ \\
\hline & $\mathrm{D}^{\prime}$ & & 130 & 5.0 & $0.4 \pm 0.2$ & $1.3 \pm 0.3$ \\
\hline & $\mathrm{W}^{\prime}$ & & 303 & 3.3 & $0.3 \pm 0.2$ & $1.2 \pm 0.4$ \\
\hline & $\mathrm{D}$ & & 80 & 3.6 & $1 \pm 0.4$ & $0.8 \pm 0.3$ \\
\hline & Year 1 & & 1148 & 4.1 & $0.6 \pm 0.4$ & $0.9 \pm 0.4$ \\
\hline & Year 2 & & 1092 & 4.0 & $0.5 \pm 0.3$ & $1.1 \pm 0.4$ \\
\hline & Total & & 3886 & 4.0 & $0.6 \pm 0.4$ & $0.9 \pm 0.4$ \\
\hline
\end{tabular}

almost exactly the same pattern for both cities. It ranges between [0.18-1.52] in Abidjan and [0.14-1.85] for Cotonou. Average values are 0.87 and 0.91 for Abidjan and Cotonou, respectively. The seasonal cycle of the AOD tends to be opposite in phase with AOD, showing lower values during the long dry seasons. The observed seasonal cycle could reflect the impact of mineral dust on the atmospheric column during the Harmattan as mineral dust transport is associated with high AOD and a low Ångström exponent (Toledano et al., 2007; Verma et al., 2015).

The increase in the Angström exponent during the long wet season (W) tends to be correlated with the start of the 
Table 2. Seasonal average of $\mathrm{PM}_{2.5}$ concentrations, carbonaceous matter and ratio between $\mathrm{PM}_{2.5}$ and AOD for Abidjan/domestic fires (ADF), Abidjan/traffic (AT) Abidjan/waste burning (AL) and Cotonou/traffic (CT) sites.

\begin{tabular}{|c|c|c|c|c|c|c|c|c|}
\hline Sites & Season & $\begin{array}{r}\text { Number of } \\
\text { samples }\end{array}$ & $\begin{array}{r}\mathrm{PM}_{2.5} \\
\left(\mu \mathrm{g} \mathrm{m}^{-3}\right)\end{array}$ & $\begin{array}{r}\mathrm{TC} \\
\left(\mu \mathrm{g} \mathrm{m}^{-3}\right)\end{array}$ & $\begin{array}{r}\mathrm{OC} \\
\left(\mu \mathrm{g} \mathrm{m}^{-3}\right)\end{array}$ & $\begin{array}{r}\mathrm{EC} \\
\left(\mu \mathrm{g} \mathrm{m}^{-3}\right)\end{array}$ & $\mathrm{OC} / \mathrm{EC}$ & $\mathrm{PM}_{2.5} / \mathrm{AOD}$ \\
\hline \multirow[t]{5}{*}{$\mathrm{ADF}$} & W & 34 & $159.5 \pm 3$ & $94 \pm 11$ & $76 \pm 8$ & $17.5 \pm 3$ & $5.5 \pm 2.5$ & \\
\hline & $\mathrm{D}^{\prime}$ & 15 & $190.5 \pm 59$ & $109.5 \pm 20$ & $91.5 \pm 25$ & $18 \pm 4$ & $5.5 \pm 0.7$ & \\
\hline & $\mathrm{W}^{\prime}$ & 17 & $139.5 \pm 22$ & $91.5 \pm 12$ & $76 \pm 16$ & $15.5 \pm 3$ & $5.0 \pm 2.0$ & \\
\hline & D & 31 & $119 \pm 27$ & $66.5 \pm 9$ & $54 \pm 8$ & $12.5 \pm 1$ & $5.0 \pm 2.5$ & \\
\hline & Total & 97 & $145 \pm 69$ & $86 \pm 35$ & $71 \pm 29$ & $15 \pm 9$ & $5.2 \pm 3.0$ & \\
\hline \multirow[t]{5}{*}{ AT } & $\mathrm{W}$ & 34 & $27.5 \pm 6$ & $17 \pm 4$ & $10 \pm 3$ & $6.5 \pm 1$ & $2.0 \pm 1.0$ & $55 \pm 30$ \\
\hline & $\mathrm{D}^{\prime}$ & 16 & $18.5 \pm 2$ & $12 \pm 1$ & $8 \pm 1$ & $4.5 \pm 1$ & $2.0 \pm 0.6$ & $62 \pm 20$ \\
\hline & $\mathrm{W}^{\prime}$ & 18 & $40 \pm 11$ & $19.5 \pm 3$ & $11.5 \pm 1$ & $7.5 \pm 2$ & $1.7 \pm 0.7$ & $133 \pm 50$ \\
\hline & D & 31 & $52 \pm 22$ & $28.5 \pm 5$ & $20 \pm 7$ & $8.5 \pm 2$ & $2.5 \pm 1.0$ & $74 \pm 54$ \\
\hline & Total & 99 & $32 \pm 25$ & $19 \pm 12$ & $12 \pm 10$ & $7 \pm 4$ & $2.0 \pm 1.0$ & \\
\hline \multirow[t]{5}{*}{$\mathrm{AL}$} & W & 35 & $21 \pm 4$ & $11 \pm 5$ & $7.5 \pm 1$ & $4.5 \pm 1$ & $2.5 \pm 1.5$ & \\
\hline & $\mathrm{D}^{\prime}$ & 16 & $18 \pm 6$ & $10 \pm 4$ & $6.5 \pm 3$ & $4.5 \pm 1$ & $1.5 \pm 0.7$ & \\
\hline & $\mathrm{W}^{\prime}$ & 18 & $26.5 \pm 2$ & $12.5 \pm 6$ & $9 \pm 4$ & $4 \pm 1$ & $2.0 \pm 1.0$ & \\
\hline & D & 32 & $48 \pm 1$ & $21 \pm 4$ & $15.5 \pm 2$ & $6 \pm 1$ & $3.0 \pm 1.5$ & \\
\hline & Total & 101 & $28 \pm 19$ & $14 \pm 8$ & $10 \pm 6$ & $4 \pm 3$ & $2.2 \pm 2.0$ & \\
\hline \multirow[t]{5}{*}{ CT } & W & 36 & $19 \pm 7$ & $8.5 \pm 2$ & $7 \pm$ & $2 \pm 1$ & $4.0 \pm 1.7$ & $38 \pm 24$ \\
\hline & $\mathrm{D}^{\prime}$ & 16 & $14 \pm 3$ & $5.5 \pm 2$ & $4 \pm 1$ & $1 \pm 1$ & $3.5 \pm 1.0$ & $35 \pm 32$ \\
\hline & $\mathrm{W}^{\prime}$ & 18 & $29.5 \pm 5$ & $9 \pm 1$ & $7 \pm 1$ & $2 \pm 1$ & $3.2 \pm 1.0$ & $98 \pm 69$ \\
\hline & D & 32 & $57 \pm 52$ & $16 \pm 11$ & $12 \pm 10$ & $3 \pm 2$ & $3.5 \pm 2.0$ & $57 \pm 31$ \\
\hline & Total & 102 & $32 \pm 32$ & $10 \pm 7$ & $8 \pm 6$ & $2 \pm 1$ & $3.5 \pm 1.0$ & \\
\hline
\end{tabular}

rainy season (see Fig. 6) and is associated with a decrease in the AOD, probably reflecting the impact of rainfall on aerosol scavenging. The average Ångström exponent during the short dry and wet season $\left(\mathrm{D}^{\prime}\right.$ and $\left.\mathrm{W}^{\prime}\right)$ is 1.2 in Abidjan and 1.3 in Cotonou, which are typical values for urban aerosols (Benkhalifa et al., 2017). The minimum AOD reached during $\mathrm{W}^{\prime}$ is at about 0.3 in both cities. Slight differences between both cities can be observed. The AOD is higher in Cotonou during the dry season: this could be attributed to the fact that Cotonou is more affected by dust transport. The large difference is the precipitation regime, Abidjan having more rainfall $(1763 \mathrm{~mm})$ than Cotonou $(1084 \mathrm{~mm})$; this does not have a clear impact on the AOD level. However, it can explain the fact that less measurements are available during the wet season for Abidjan than Cotonou because of cloud cover.

The $\mathrm{W}$ season shows the lowest Ångström exponent value and low AOD, which reflects the contribution of maritime aerosols (Kaskaoutis et al., 2009; Verma et al., 2015; Toledano et al., 2007). Figure 7 shows that during the largest peak values (above $100 \mu \mathrm{g} \mathrm{m}^{-3}$ ) in the dry season, D1 and D2 are associated with an Ångström exponent close to 0.5, which means that advected dust might sporadically contribute to the increase in the ground-level $\mathrm{PM}_{2.5}$ concentration.

\subsubsection{Carbonaceous components}

The relationship between $\mathrm{OC}$ and $\mathrm{EC}$ and the mass ratio of OC to EC can be used to identify origins, emission and transformation characteristics of carbonaceous aerosols (Ouafo-Leumbe et al., 2017; Turpin and Huntzicker, 1991). As shown in Table 2, the average OC / EC ratio was 5.2 \pm 3.0 at $\mathrm{ADF}, 2.0 \pm 1.0$ at $\mathrm{AT}, 2.2 \pm 2.0$ at $\mathrm{AL}$ and $3.5 \pm 1.0$ at $\mathrm{CT}$ during the study period. Average OC / EC ratios in the wet season $\mathrm{W}$ were $5.5 \pm 2.5$ at $\mathrm{ADF}, 2.0 \pm 1.0$ at $\mathrm{AT}, 2.5 \pm 1.5$ at $\mathrm{AL}$ and $4.0 \pm 1.7$ at CT. During the dry season $\mathrm{D}$, average $\mathrm{OC} / \mathrm{EC}$ was $5.0 \pm 2.5$ at ADF, $2.5 \pm 1.0$ at AT, $3.0 \pm 1.5$ at $\mathrm{AL}$ and $3.5 \pm 2.0$ at $\mathrm{CT}$. The average $\mathrm{OC} / \mathrm{EC}$ ratio during the wet season $\mathrm{W}^{\prime}$ was $5.0 \pm 2.0$ at $\mathrm{ADF}, 1.7 \pm 0.7$ at $\mathrm{AT}$, $2.0 \pm 1.0$ at $\mathrm{AL}$ and $3.2 \pm 1.0$ at CT. The average $\mathrm{OC} / \mathrm{EC}$ ratio was $5.5 \pm 0.7$ at $\mathrm{ADF}, 2.0 \pm 0.6$ at $\mathrm{AT}, 1.5 \pm 0.7$ at $\mathrm{AL}$ and $3.5 \pm 1.0$ at $\mathrm{CT}$ during the dry season $\mathrm{D}^{\prime}$.

As shown in Fig. 8 the OC / EC ratio has a seasonal variability, showing higher values during the long dry season, except for ADF, which shows a rather constant ratio across season but is associated with the largest dispersion of observations. The $\mathrm{OC}$ and EC average concentrations measured at the AT, CT and AL sites are high in seasons $\mathrm{D}$ and $\mathrm{W}^{\prime}$ (see Table 2) as expected from higher emission from biomass fires. The low average values of OC and EC are measured in 

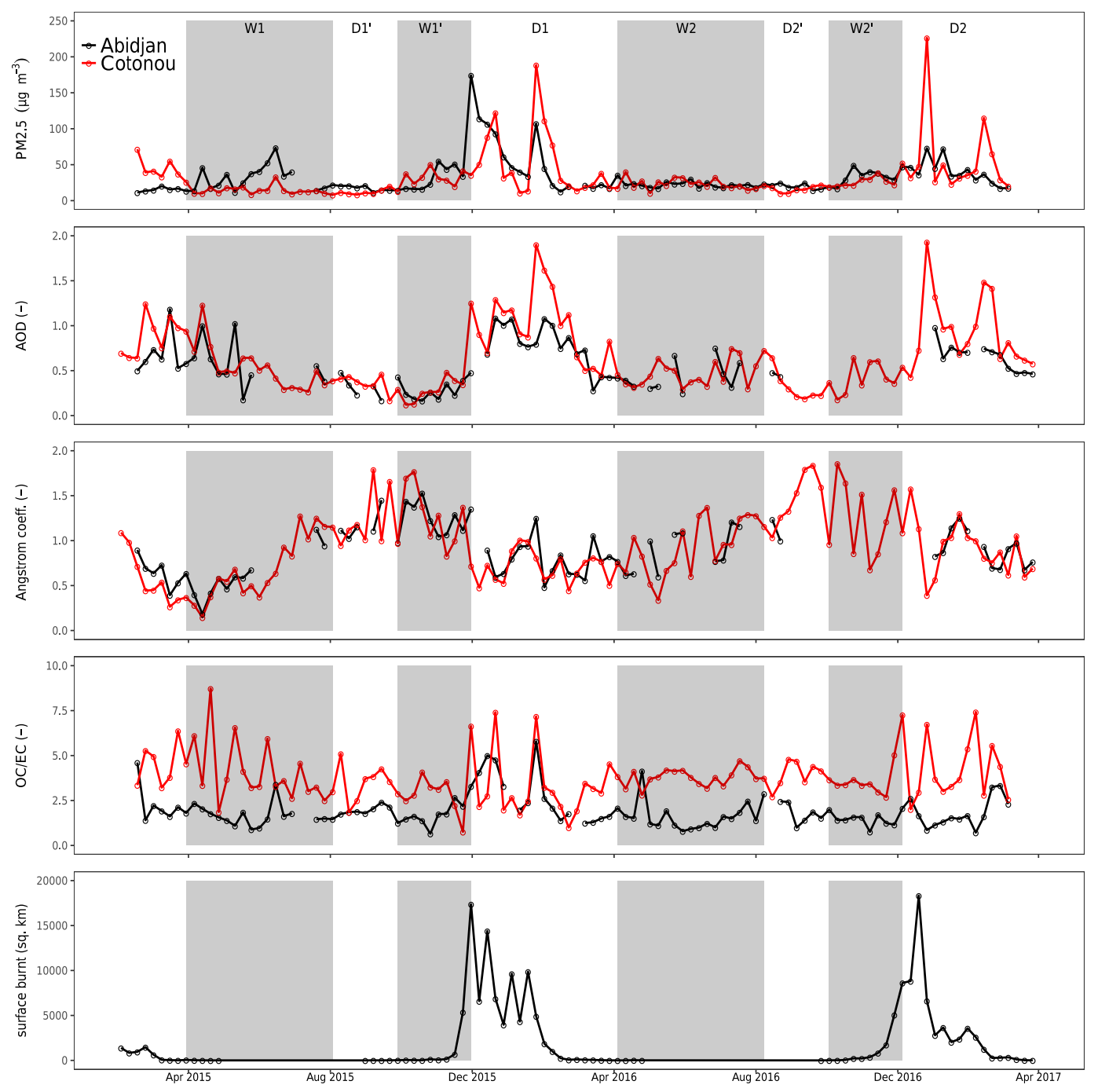

Figure 7. Weekly mean $\mathrm{PM}_{2.5}$, AOD, Ångström exponent and OC / EC ratio observed at Cotonou and Abidjan traffic sites from February 2015 to March 2017. The surface burnt is the weekly total of the MODIS MCD64A1 product burnt surface areas for the region from $7^{\circ} \mathrm{W}$ to $4^{\circ} \mathrm{E}$ and 4 to $10^{\circ} \mathrm{N}$.

season $\mathrm{D}^{\prime}$ at the AT, $\mathrm{CT}$ and $\mathrm{AL}$ sites in conjunction with low $\mathrm{PM}_{2.5}$ concentrations.

We also notice in Fig 7 that the $\mathrm{OC} / \mathrm{EC}$ ratio shows sharp variations towards high values (above 5) for weeks associated with high $\mathrm{PM}_{2.5}$ and AOD, indicating a possible contribution of biomass burning by-products. Those increases are also associated with an increase in the OC concentrations (Fig. 5). Regarding the possible contribution of biomass burning emissions, we have also reported in Fig 7 the MDC64A1 surface burnt in the geographical area $7^{\circ} \mathrm{W}-$ $4^{\circ} \mathrm{E}$ and $10-4^{\circ} \mathrm{N}$. As expected, the largest part of the vegetation burns during the dry season. However, we observe that a significant part of biomass burning emissions occurs during the short wet season. Indeed, the percentage of the total surface burnt is 21 and $79 \%$ for $\mathrm{W}^{\prime}$ and $\mathrm{D}$, respectively. It shows that biomass burning emissions may have a large rel- ative impact on $\mathrm{PM}_{2.5}$ during the short wet season and could explain the increase in the $\mathrm{PM}_{2.5}$ concentrations from after the short dry season $\mathrm{D}^{\prime}$.

Carbonaceous aerosols contribute significantly to the $\mathrm{PM}_{2.5}$. We remark that, after the analysis of particulate carbon species at the four sites, $\mathrm{OC}$ is the predominant contributor to TC. During the study period, TC at the AT, CT, AL and ADF sites accounted for an average 64, 37, 55 and $62 \%$ of $\mathrm{PM}_{2.5}$, respectively. $\mathrm{PM}_{2.5}$ at the AT, CT, AL and ADF consisted of 24, 8, 17 and $11 \%$ elemental carbon and 39, 29, 38 and $51 \%$ organic carbon, respectively. These percentages of particulate carbon species obtained indicated that more carbonaceous species in $\mathrm{PM}_{2.5}$ particles. When we compare the percentages of carbonaceous species at the AT and CT sites, it can be seen that the percentage of particulate carbon species obtained at the AT site is about 1.7 times higher than 


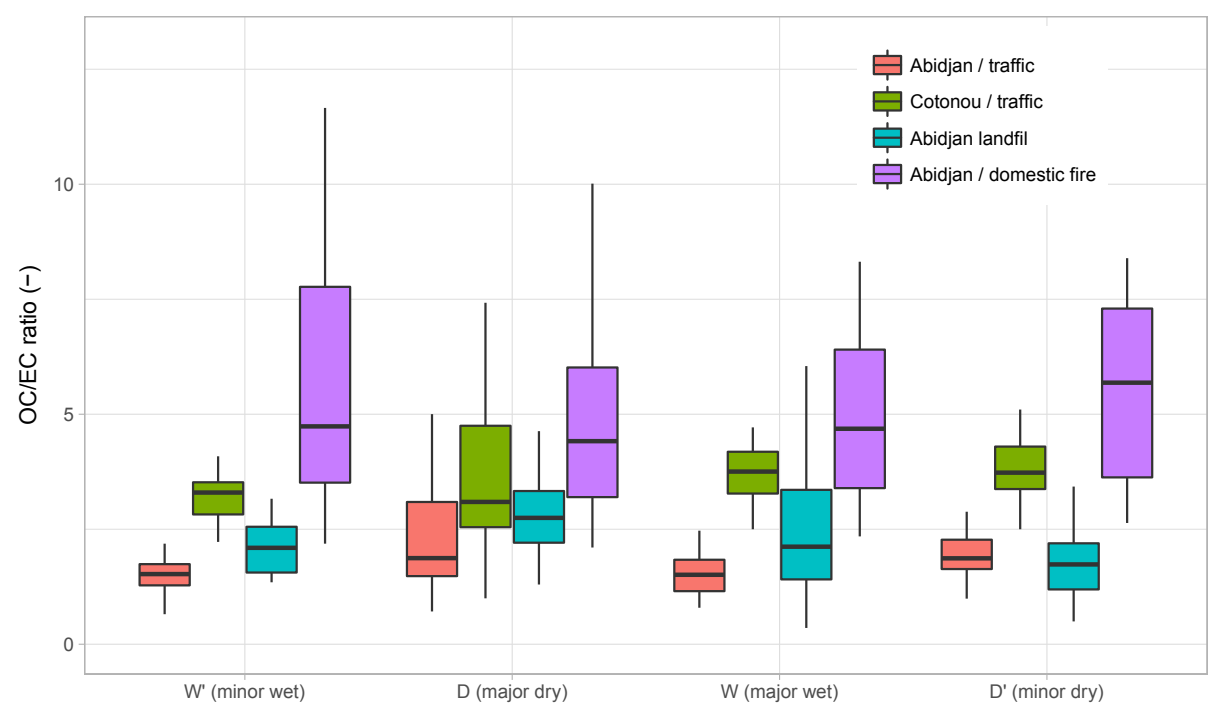

Figure 8. Mean seasonal variation in the OC / EC ratio for the different sites. Each box shows the median and the first and third quartiles (the lower and upper hinges) and the largest and lowest values (upper and upper whiskers).

the percentages obtained at the CT site. From the percentages obtained at the traffic sites, we can say that emissions of particulate carbon species are very important at the AT. These results allow us to confirm the domination of diesel and fuel at the AT and CT site, respectively.

\subsubsection{AOD and $\mathrm{PM}_{2.5}$}

AOD can also be used for a proxy of $\mathrm{PM}_{2.5}$ (Kacenelenbogen et al., 2006) as both quantities tends to be correlated. However, deducing surface $\mathrm{PM}_{2.5}$ from columnar AOD is not straightforward (Wang, 2003; Zhou et al., 2016). The higher Pearson's correlation coefficient $\mathrm{R}$ is obviously obtained during the long dry season when both AOD and $\mathrm{PM}_{2.5}$ are largely the same (see Fig. 7). The correlation coefficient is 0.74 in Cotonou and 0.65 in Abidjan. Weak or even no correlation are observed in the other season. The ratio between $\mathrm{PM}_{2.5}$ and AOD is an indicator of the link between surface-level pollution and the atmospheric column. A large $\mathrm{PM}_{2.5}$ / AOD indicates that aerosols are confined to lower altitudes. The highest $\mathrm{PM}_{2.5}$ / AOD ratio is observed during the short wet season $\mathrm{W}^{\prime}$ (Table 2) highlighting a possible stagnation of pollution during this period. Conversely, the lowest ratio is observed during the long wet season $\mathrm{W}$, which tends to indicate transport aloft of aerosols.

As shown in Awanou et al. (1991) and Parker and DiopKane (2017), the analysis of the wind roses shows that the prevailing wind are southwest all year long at those coastal sites. Northerly winds (Harmattan winds) appear only during the long dry season. The seasonal averages of wind speeds in both cities range between 2.9 and $3.5 \mathrm{~m} \mathrm{~s}^{-1}$ in Abidjan and between 3.6 and $5.0 \mathrm{~m} \mathrm{~s}^{-1}$ in Cotonou. We have noticed that the wind intensity is the highest in $\mathrm{D}^{\prime}$ (Table 1). This in- crease in the wind intensity during the short wet season also corresponds to a minimum in air temperature (Fig. 6). The increase in wind intensity favours the dispersion of pollutant during $\mathrm{D}^{\prime}$ seasons and may explain the decrease in the $\mathrm{PM}_{2.5}$ concentrations. Inversely, the wind intensity is lowest during the long dry season D1 and D2, while the $\mathrm{PM}_{2.5}$ concentrations and AOD are the highest.

\subsection{Discussion}

Our results show that the average concentration of $\mathrm{PM}_{2.5}$ at our urban sites is around $30 \mu \mathrm{g} \mathrm{m}^{-3}$, with $28 \mu \mathrm{g} \mathrm{m}^{-3}$ for AL and $32 \mu \mathrm{g} \mathrm{m}^{-3}$ for both traffic sites in Benin (CT) and Côte d'Ivoire (AT), whereas $145 \mathrm{\mu g} \mathrm{m}^{-3}$ is obtained for ADF. Such values are presented in Fig. 9 with other measurements existing in Africa for different cities. It is interesting to underline that all the values including our measurements are higher by a factor of 2-14 than the WHO guidelines. The review paper of Naidja et al. (2017) on road traffic sites gives values slightly higher than our traffic values: $41 \mu \mathrm{g} \mathrm{m}^{-3}$ for Harare in Zimbawe (Kuvarega and Taru, 2008), $51 \mu \mathrm{g} \mathrm{m}^{-3}$ for Kénitra in Marocco (Zghaid et al., 2009) and $58 \mu \mathrm{g} \mathrm{m}^{-3}$ for Constantine in Algeria (Terrouche et al., 2016). In their study over Accra in Ghana, Dioniso et al. (2010) reveal that the geometric mean of $\mathrm{PM}_{2.5}$ concentration is included in the $39-53 \mu \mathrm{g} \mathrm{m}^{-3}$ range for roadside sites, whereas it is in the $30-70 \mu \mathrm{g} \mathrm{m}^{-3}$ range for residential sites. We may note that our values are globally of the same order than in Accra with higher values observed in residential sites including more or less domestic fire activities than in traffic sites. In Dakar in Senegal, Dieme et al. (2012) and Doumbia et al. (2012) report $\mathrm{PM}_{2.5}$ at 75 and $50 \mu \mathrm{g} \mathrm{m}^{-3}$, respectively, close to the value found by Zakey et al. $\left(2008 ; 85 \mu \mathrm{g} \mathrm{m}^{-3}\right)$ in Cairo, 


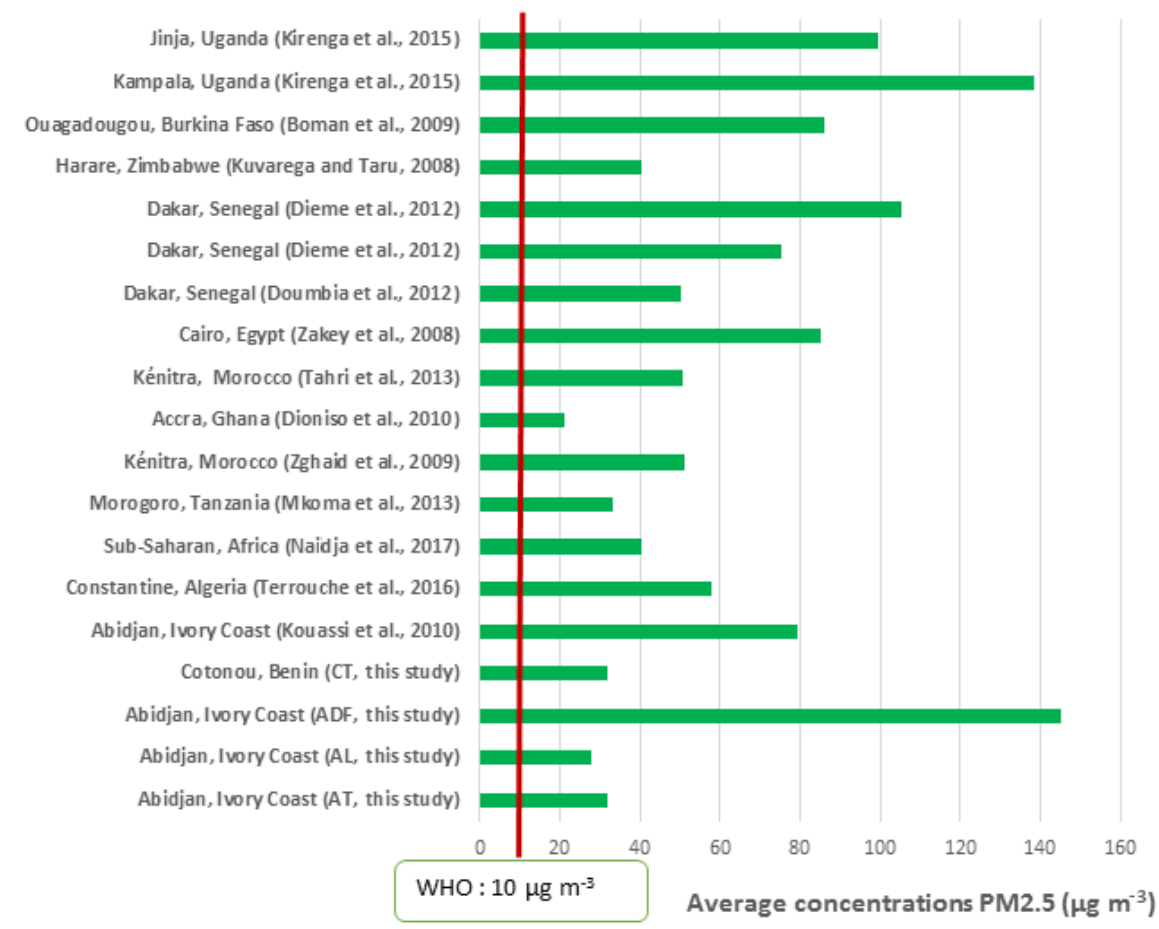

Figure 9. Comparison of $\mathrm{PM}_{2.5}$ mass concentrations at the four sites with those in other African cities. Red vertical line illustrates current WHO guideline.

Egypt. These values are slightly higher than ours. It may be noted that those latter sites are largely influenced by mineral dust. Finally, it may be seen that our values except for ADF are in agreement with those obtained from satellite data by van Donkelaar et al. (2010) $\left(35 \mu \mathrm{g} \mathrm{m}^{-3}\right)$ in sub-Saharan western African area.

At the global scale, we should note that our traffic site values are higher than the ones found for European cities but smaller than those of Asian cities. Indeed, Querol et al. (2004) have reported a range of $20-30 \mu \mathrm{g} \mathrm{m}^{-3}$ for $\mathrm{PM}_{2.5}$ concentrations at European traffic sites, whereas in China, Zhang et al. (2011) and Gu et al. (2010) have reported average values of 72 and $100 \mu \mathrm{g} \mathrm{m}^{-3}$ for urban roadside sites in Xiamen and Tianjin, respectively. Note that $\mathrm{PM}_{2.5}$ value obtained by Zhang et al. (2015) for a residential site in Wanzhou $\left(125 \mu \mathrm{g} \mathrm{m}^{-3}\right)$ is of the order of our value for the domestic fire sites.

In terms of carbonaceous aerosol, the OC concentrations in $\mathrm{PM}_{2.5}$ at the CT, AT, AL and ADF sites are 8, 12, 10 and $71 \mu^{-3} \mathrm{~m}^{-3}$, respectively. These OC concentrations are higher than the one found for an urban site in Paris, France $\left(5.9 \mathrm{~g} \mathrm{~m}^{-3}\right)$ (Favez, 2008), or a traffic site in Helsinki $\left(3 \mu \mathrm{g} \mathrm{m}^{-3}\right)$ (Viidanoja, 2002). Values of CT and AT are of the order of those of an urban site in Milan, Italy $\left(9.2 \mu \mathrm{g} \mathrm{m}^{-3}\right)$ (Lonati et al., 2007), whereas they are about half the value of OC concentrations measured at an urban site in Cairo, Egypt $\left(22.4 \mu \mathrm{g} \mathrm{m}^{-3}\right)$ (Favez, 2008), in Agra, India $\left(22.8 \mu \mathrm{g} \mathrm{m}^{-3}\right)$ (Tripti et al., 2013), and in Taiyuan, China $\left(28.9 \mu \mathrm{g} \mathrm{m}^{-3}\right)$
(Meng et al., 2007). Note that our measurements at the ADF site are much higher than all the values observed at other sites. The EC concentration at the CT and AT sites is 2 and $7 \mu \mathrm{g} \mathrm{m}^{-3}$, respectively. Such an EC concentration at AT shows the large contribution of diesel engines in Abidjan. It is similar to the traffic site in Dakar $\left(10.5 \mu \mathrm{g} \mathrm{m}^{-3}\right.$ ) (Doumbia et al., 2012) and to urban sites in Cairo, Egypt $\left(7.8 \mu \mathrm{g} \mathrm{m}^{-3}\right)$, and in Beijing, China $\left(7.8 \mu \mathrm{g} \mathrm{m}^{-3}\right)$ (Favez, 2008). At the Agra traffic site, India, the BC value $\left(19.4 \mu \mathrm{g} \mathrm{m}^{-3}\right.$ ) (Pachauri et al., 2013) is much higher than at our traffic sites. That of Xiamen, China (3.5 $\mathrm{g} \mathrm{m}^{-3}$ ) (Zhang et al., 2011), is lower. The EC concentration in Cotonou is close to the one found in European cities like Milan, Italy $\left(1.4 \mu \mathrm{g} \mathrm{m}^{-3}\right)$, and Paris, France, $\left(1.7 \mu \mathrm{g} \mathrm{m}^{-3}\right)$, or in Yokohama $\left(1.9 \mu \mathrm{g} \mathrm{m}^{-3}\right)$ (Khan et al., 2010), but it is higher than in Helsinki $\left(1.1 \mu \mathrm{g} \mathrm{m}^{-3}\right)$.

To conclude, OC / EC ratios obtained at our sites are within the common ranges reported in the literature. Indeed, following the above-mentioned literature data, OC / EC ratios range between 2.7 in Helsinki, 2.9 in Cairo, 3.5 in Paris, 6.6 in Milan and 6.7 in Agra. In our study, averages of the $\mathrm{OC} / \mathrm{EC}$ ratio are $2 \pm 1$ at $\mathrm{AT}, 4 \pm 1$ at $\mathrm{CT}, 3 \pm 2$ at $\mathrm{AL}$ and $5 \pm 3$ at ADF. It is interesting to underline that either in our study or in the literature data, the highest values are due to the predominant influence of sources with incomplete combustion such as domestic fires and two-wheel vehicle traffic, whereas the lowest OC / EC ratios are typical of much more complete combustion such as diesel engines (Mmari et al., 2013). 


\section{Conclusion}

This study reports new and unique observations of weekly $\mathrm{PM}_{2.5}$ mass and carbonaceous aerosol concentrations in the vicinity of major combustion sources, i.e. traffic, burning of waste at landfill and smoking activity in coastal cities of southern West Africa. Traffic emissions were investigated in two different environments: one is dominated by two-wheeled vehicles (Cotonou) and the other one by fourwheeled vehicles (Abidjan). Additionally, the AOD was also measured for the first time in Abidjan and Cotonou on a daily basis. The period of observations spans from February 2015 to March 2017. Our findings can be summarised as follows.

The average $\mathrm{PM}_{2.5}$ concentrations for our urban traffic and waste burning sites are about $30 \mu \mathrm{g} \mathrm{m}^{-3}$ and in the range of those of previous studies in sub-Saharan western Africa. They are 3 times higher than the concentrations recommended by the World Health Organization.

We observe large similarities in the seasonal cycle of $\mathrm{PM}_{2.5}$ and AOD between both urban sites, with an overall increase in concentrations in AOD and $\mathrm{PM}_{2.5}$ during the major dry season. During this period AOD and $\mathrm{PM}_{2.5}$ are well correlated, suggesting that most of the particles are located in the lower part of the atmosphere.

The spikes in $\mathrm{PM}_{2.5}$ weekly time series can be associated with the contribution of dust transport or biomass burning activities as revealed by the analysis of the EC / OC ratio, Ångström exponent and MODIS burnt areas. Those spikes are observed during the long dry season, while the short dry season shows low $\mathrm{PM}_{2.5}$ concentrations, possibly due to the absence of biomass burning influence and the enhancement of the atmospheric dispersion in relation with the increase in wind intensity.

The average OC / EC ratio is 4 in Cotonou and 2 in Abidjan, clearly indicating the larger contribution of emissions by the motorcycles in Cotonou than in Abidjan, mostly dominated by diesel vehicles.

The observations of domestic fire emissions at the open-air smoking courtyard in Abidjan show a weekly average $\mathrm{PM}_{2.5}$ concentration of $145 \mathrm{\mu g} \mathrm{m}^{-3}$, indicating that open-air smoking activity could be a large contributor to air pollution. We observe a different seasonal cycle at this site than at other urban ones.

This 2-year-long field campaign focused on combustion aerosol sources in the emergent cities of coastal SWA provides a first and unique dataset for a better understanding of the impact of such pollutants on health and the environment in this part of the world.

Data availability. The pollution data used in this study are original and are available in Table S3 in the Supplement.
Supplement. The supplement related to this article is available online at: https://doi.org/10.5194/acp-18-6275-2018-supplement.

Competing interests. The authors declare that they have no conflict of interest.

Special issue statement. This article is part of the special issue "Results of the project "Dynamics-aerosol-chemistry-cloud interactions in West Africa" (DACCIWA) (ACP/AMT inter-journal SI)". It is not associated with a conference.

Acknowledgements. This work has received funding from the European Union 7th Framework Programme (FP7/2007-2013) under Grant Agreement no. 603502 (EU project DACCIWA: Dynamics-Aerosol-Chemistry-Cloud Interactions in West Africa). The authors would like to thank the AUF (Agence Universitaire de la Francophonie) for funding his stays in Laboratoire d'Aérologie of Toulouse ( 3 months per year for 3 years).

Edited by: Mathew Evans

Reviewed by: two anonymous referees

\section{References}

Adetunji, J., McGregor, J., and Ong, C. K.: Harmattan haze, Weather, 34, 430-436, https://doi.org/10.1002/j.14778696.1979.tb03389.x, 1979.

Adjiri, O. A., Mafou, C. K., and Konan, P. K.: Impact of Akouedo landfill (Abidjan - Côte d'Ivoire) on the populations: socio-economic and environmental study, available at: http://www.ijias.issr-journals.org/abstract.php?article= IJIAS-15-235-01 (last access: 24 May 2017), 2015.

Ångström, A.: Techniques of determinig the turbidity of the atmosphere, Tellus, 13, 214-223, https://doi.org/10.3402/tellusa.v13i2.9493, 1961.

Awanou, C. N., Degbey, J. M., and Ahlonsou, E.: Estimation of the mean wind energy available in Benin (Ex Dahomey), Renew. Energ., 1, 845-853, 1991.

Ayi Fanou, L., Mobio, T. A., Creppy, E. E., Fayomi, B., Fustoni, S., Møller, P., Kyrtopoulos, S., Georgiades, P., Loft, S., Sanni, A., Skov, H., Øvrebø, S., and Autrup, H.: Survey of air pollution in Cotonou, Benin - air monitoring and biomarkers, Sci. Total Environ., 358, 85-96, https://doi.org/10.1016/j.scitotenv.2005.03.025, 2006.

Balarabe, M., Abdullah, K., and Nawawi, M.: Seasonal variations of aerosol optical properties and identification of different aerosol types based on AERONET data over sub-Sahara West-Africa, Atmospheric and Climate Sciences, 6, 13-28, 2016.

Benkhalifa, J., Léon, J. F., and Chaabane, M.: Aerosol optical properties of Western Mediterranean basin from multi-year AERONET data, J. Atmos. Sol.-Terr. Phys., 164, 222-228, 2017.

Boers, R., van Weele, M., van Meijgaard, E., Savenije, M., Siebesma, A. P., Bosveld, F., and Stammes, P.: Observations and projections of visibility and aerosol optical thickness (1956$2100)$ in the Netherlands: impacts of time-varying aerosol com- 
position and hygroscopicity, Environ. Res. Lett., 10, 015003, https://doi.org/10.1088/1748-9326/10/1/015003, 2015.

Boman, J., Lindén, J., Thorsson, S., Holmer, B., and Eliasson, I.: A tentative study of urban and suburban fine particles $\left(\mathrm{PM}_{2.5}\right)$ collected in Ouagadougou, Burkina Faso, X-Ray Spectrom., 38, 354-362, https://doi.org/10.1002/xrs.1173, 2009.

Cachier, H., Liousse, C., Buat-Menard, P., and Gaudichet, A.: Particulate content of savanna fire emissions, J. Atmos. Chem., 22, 123-148, 1995.

Cao, J. J., Lee, S. C., Ho, K. F., Zhang, X. Y., Zou, S. C., Fung, K., Chow, J. C., and Watson, J. G.: Characteristics of carbonaceous aerosol in Pearl River Delta Region, China during 2001 winter period, Atmos. Environ., 37, 1451-1460, https://doi.org/10.1016/S1352-2310(02)01002-6, 2003.

Chiappini, L., Verlhac, S., Aujay, R., Maenhaut, W., Putaud, J. P., Sciare, J., Jaffrezo, J. L., Liousse, C., Galy-Lacaux, C., Alleman, L. Y., Panteliadis, P., Leoz, E., and Favez, O.: Clues for a standardised thermal-optical protocol for the assessment of organic and elemental carbon within ambient air particulate matter, Atmos. Meas. Tech., 7, 1649-1661, https://doi.org/10.5194/amt7-1649-2014, 2014.

Chow, J. C., Watson, J. G., Pritchett, L. C., Pierson, W. R., Frazier, C. A., and Purcell, R. G.: The dri thermal/optical reflectance carbon analysis system: description, evaluation and applications in U.S. Air quality studies, Atmos. Environ. A Gen., 27, 11851201, https://doi.org/10.1016/0960-1686(93)90245-T, 1993.

Chow, J. C., Watson, J. G., Fujita, E. M., Lu, Z., Lawson, D. R., and Ashbaugh, L. L.: Temporal and spatial variations of $\mathrm{PM}_{2.5}$ and $\mathrm{PM}_{10}$ aerosol in the Southern California Air Quality Study, Atmos. Environ., 28, 2061-2080, https://doi.org/10.1016/13522310(94)90474-X, 1994.

Chow, J. C., Watson, J. G., Kuhns, H., Etyemezian, V., Lowenthal, D. H., Crow, D., Kohl, S. D., Engelbrecht, J. P., and Green, M. C.: Source profiles for industrial, mobile, and area sources in the Big Bend Regional Aerosol Visibility and Observational Study, Chemosphere, 54, 185-208, https://doi.org/10.1016/j.chemosphere.2003.07.004, 2004.

Chow, J. C., Chen, L.-W. A., Watson, J. G., Lowenthal, D. H., Magliano, K. A., Turkiewicz, K., and Lehrman, D. E.: $\mathrm{PM}_{2.5}$ chemical composition and spatiotemporal variability during the California Regional $\mathrm{PM}_{10} / \mathrm{PM}_{2.5}$ Air Quality Study (CRPAQS), J. Geophys. Res.-Atmos., 111, D10S04, https://doi.org/10.1029/2005JD006457, 2006.

Delmas, R. A., Druilhet, A., Cros, B., Durand, P., Delon, C., Lacaux, J. P., Brustet, J. M., Serca, D., Affre, C., and Guenther, A.: Experiment for regional sources and sinks of oxidants (EXPRESSO): an overview, J. Geophys. Res.-Atmos., 104, 3060930624, 1999.

Dieme, D., Cabral-Ndior, M., Garçon, G., Verdin, A., Billet, S., Cazier, F., Courcot, D., Diouf, A., and Shirali, P.: Relationship between physicochemical characterization and toxicity of fine particulate matter $\left(\mathrm{PM}_{2.5}\right)$ collected in Dakar city (Senegal), Environ. Res., 113, 1-13, https://doi.org/10.1016/j.envres.2011.11.009, 2012.

Dionisio, K. L., Rooney, M. S., Arku, R. E., Friedman, A. B., Hughes, A. F., Vallarino, J., Agyei-Mensah, S., Spengler, J. D., and Ezzati, M.: Within-neighborhood patterns and sources of particle pollution: mobile monitoring and geographic informa- tion system analysis in four communities in Accra, Ghana, Environ. Health Persp., 118, 607-613, 2010b.

Djossou, J., Akpo, A., and Afféwé, J.: Dynamics of the inter tropical front and rainy season onset in Benin, Curr. J. Appl. Sci. Technol., 24, 1-15, https://doi.org/10.9734/CJAST/2017/36832, 2017.

Dockery, D. W. and Pope, C. A.: Acute respiratory effects of particulate air pollution, Annu. Rev. Publ. Health, 15, 107-132, https://doi.org/10.1146/annurev.pu.15.050194.000543, 1994.

Dossou, K. M. and Glehouenou-Dossou, B.: The vulnerability to climate change of Cotonou (Benin) the rise in sea level, Environ. Urban., 19, 65-79, 2007.

Dou, J., Lin, P., Kuang, B.-Y., and Yu, J. Z.: Reactive oxygen species production mediated by humic-like substances in atmospheric aerosols: enhancement effects by pyridine, imidazole, and their derivatives, Environ. Sci. Technol., 49, 6457-6465, https://doi.org/10.1021/es5059378, 2015.

Doumbia, E. H. T., Liousse, C., Galy-Lacaux, C., Ndiaye, S. A., Diop, B., Ouafo, M., Assamoi, E. M., Gardrat, E., Castera, P., Rosset, R., Akpo, A., and Sigha, L.: Real time black carbon measurements in West and Central Africa urban sites, Atmos. Environ., 54, 529-537, https://doi.org/10.1016/j.atmosenv.2012.02.005, 2012.

Ernest, A. K., Blaise, K. Y., Michel, K. A., Gbombélé, S., Nagnin, S., and Jean, B.: Étude de la variabilité hydroclimatique et de ses conséquences sur les ressources en eau du Sud forestier et agricole de la Côte d'Ivoire: cas de la région d'AbidjanAgboville, Int. J. Pure Appl. Biosci., 1, 30-50, 2013.

Favez, O.: Caractérisation physico-chimique de la pollution particulaire dans des mégapoles contrastées, Université Paris, Diderot, Paris, 2008.

Fourn, L. and Fayomi, E. B.: Pollution atmosphérique en milieu urbain à Cotonou et à Lokossa, Bénin, B. Soc. Pathol. Exot., 99, 264-268, 2006.

Galy-Lacaux, C., Laouali, D., Descroix, L., Gobron, N., and Liousse, C.: Long term precipitation chemistry and wet deposition in a remote dry savanna site in Africa (Niger), Atmos. Chem. Phys., 9, 1579-1595, https://doi.org/10.5194/acp-9-1579-2009, 2009.

Gu, J., Bai, Z., Liu, A., Wu, L., Xie, Y., Li, W., Dong, H., and Zhang, X.: Characterization of atmospheric organic carbon and element carbon of $\mathrm{PM}_{2.5}$ and $\mathrm{PM}_{10}$ at Tianjin, China, Aerosol Air Qual. Res., 10, 167-176, 2010.

Holben, B. N., Eck, T. F., Slutsker, I., Tanre, D., Buis, J. P., Setzer, A., Vermote, E., Reagan, J. A., Kaufman, Y. J., and Nakajima, T.: AERONET - a federated instrument network and data archive for aerosol characterization, Remote Sens. Environ., 66, 1-16, 1998.

Horowitz, H. M., Garland, R. M., Thatcher, M., Landman, W. A., Dedekind, Z., van der Merwe, J., and Engelbrecht, F. A.: Evaluation of climate model aerosol seasonal and spatial variability over Africa using AERONET, Atmos. Chem. Phys., 17, 1399914023, https://doi.org/10.5194/acp-17-13999-2017, 2017.

Kacenelenbogen, M., Léon, J.-F., Chiapello, I., and Tanré, D.: Characterization of aerosol pollution events in France using groundbased and POLDER-2 satellite data, Atmos. Chem. Phys., 6, 4843-4849, https://doi.org/10.5194/acp-6-4843-2006, 2006.

Kaskaoutis, D. G., Badarinath, K. V. S., Kumar Kharol, S., Rani Sharma, A., and Kambezidis, H. D.: Variations in the 
aerosol optical properties and types over the tropical urban site of Hyderabad, India, J. Geophys. Res.-Atmos., 114, D22204, https://doi.org/10.1029/2009JD012423, 2009.

Kaufman, Y. J., Holben, B. N., Slutsker, I., and Smirnov, A.: Will aerosol measurements from Terra and Aqua polar orbiting Satellites represent the daily aerosol abundance and properties?, Geophys. Res. Lett., 27, 3861-3864, 2000.

Keita, S., Liousse, C., Yoboué, V., Dominutti, P., Guinot, B., Assamoi, E.-M., Borbon, A., Haslett, S. L., Bouvier, L., Colomb, A., Coe, H., Akpo, A., Adon, J., Bahino, J., Doumbia, M., Djossou, J., Galy-Lacaux, C., Gardrat, E., Gnamien, S., Léon, J. F., Ossohou, M., N'Datchoh, E. T., and Roblou, L.: Aerosol and VOC emission factor measurements for African anthropogenic sources, Atmos. Chem. Phys. Discuss., https://doi.org/10.5194/acp-2017-944, in review, 2017.

Khan, M. F., Shirasuna, Y., Hirano, K., and Masunaga, S.: Characterization of $\mathrm{PM}_{2.5}, \mathrm{PM}_{2.5-10}$ and $\mathrm{PM}_{>10}$ in ambient air, Yokohama, Japan, Atmos. Res., 96, 159-172, https://doi.org/10.1016/j.atmosres.2009.12.009, 2010.

Kirenga, B., Meng, Q., van Gemert, F., Aanyu-Tukamuhebwa, H., Chavannes, N., Katamba, A., Obai, G., Molen, T., Schwander, S., and Mohsenin, V.: The state of ambient air quality in two Ugandan cities: a pilot cross-sectional spatial assessment, Int. J. Environ. Res. Pu., 12, 8075-8091, https://doi.org/10.3390/ijerph120708075, 2015.

Knippertz, P., Coe, H., Chiu, J. C., Evans, M. J., Fink, A. H., Kalthoff, N., Liousse, C., Mari, C., Allan, R. P., and Brooks, B.: The DACCIWA project: dynamics-aerosol-chemistry-cloud interactions in West Africa, B. Am. Meteorol. Soc., 96, 1451-1460, 2015.

Kouassi, K. S., Billet, S., Garçon, G., Verdin, A., Diouf, A., Cazier, F., Djaman, J., Courcot, D., and Shirali, P.: Oxidative damage induced in A549 cells by physically and chemically characterized air particulate matter $\left(\mathrm{PM}_{2.5}\right)$ collected in Abidjan, Côte d'Ivoire, J. Appl. Toxicol., 30, 310-320, https://doi.org/10.1002/jat.1496, 2010.

Kuvarega, A. T. and Taru, P.: Ambiental dust speciation and metal content variation in TSP, $\mathrm{PM}_{10}$ and $\mathrm{PM}_{2.5}$ in urban atmospheric air of Harare (Zimbabwe), Environ. Monit. Assess., 144, 1-14, https://doi.org/10.1007/s10661-008-0436-x, 2008.

Lacaux, J. P., Brustet, J. M., Delmas, R., Menaut, J. C., Abbadie, L., Bonsang, B., Cachier, H., Baudet, J., Andreae, M. O., and Helas, G.: Biomass burning in the tropical savannas of Ivory Coast: an overview of the field experiment Fire of Savannas (FOS/DECAFE 91), J. Atmos. Chem., 22, 195-216, 1995.

Lamarque, J.-F., Bond, T. C., Eyring, V., Granier, C., Heil, A., Klimont, Z., Lee, D., Liousse, C., Mieville, A., Owen, B., Schultz, M. G., Shindell, D., Smith, S. J., Stehfest, E., Van Aardenne, J., Cooper, O. R., Kainuma, M., Mahowald, N., McConnell, J. R., Naik, V., Riahi, K., and van Vuuren, D. P.: Historical (1850-2000) gridded anthropogenic and biomass burning emissions of reactive gases and aerosols: methodology and application, Atmos. Chem. Phys., 10, 7017-7039, https://doi.org/10.5194/acp-10-7017-2010, 2010.

Léon, J.-F., Derimian, Y., Chiapello, I., Tanré, D., Podvin, T., Chatenet, B., Diallo, A., and Deroo, C.: Aerosol vertical distribution and optical properties over M'Bour $\left(16.96^{\circ} \mathrm{W} ; 14.39^{\circ} \mathrm{N}\right)$, Senegal from 2006 to 2008, Atmos. Chem. Phys., 9, 9249-9261, https://doi.org/10.5194/acp-9-9249-2009, 2009.
Liousse, C. and Galy-Lacaux, C.: Pollution urbaine en Afrique de l'Ouest, La Météorologie, 8, 45, https://doi.org/10.4267/2042/37377, 2010.

Liousse, C., Penner, J. E., Chuang, C., Walton, J. J., Eddleman, H., and Cachier, H.: A global three-dimensional model study of carbonaceous aerosols, J. Geophys. Res.-Atmos., 101, 1941119432, https://doi.org/10.1029/95JD03426, 1996.

Liousse, C., Andreae, M. O., Artaxo, P., Barbosa, P., Cachier, H., Grégoire, J. M., Hobbs, P., Lavoué, D., Mouillot, F., Penner, J., Scholes, M., and Schultz, M. G.: Deriving global quantitative estimates for spatial and temporal distributions of biomass burning emissions, in: Emissions of Atmospheric Trace Compounds, Springer, Dordrecht, 71-113, 2004.

Liousse, C., Guillaume, B., Grégoire, J. M., Mallet, M., Galy, C., Pont, V., Akpo, A., Bedou, M., Castéra, P., Dungall, L., Gardrat, E., Granier, C., Konaré, A., Malavelle, F., Mariscal, A., Mieville, A., Rosset, R., Serça, D., Solmon, F., Tummon, F., Assamoi, E., Yoboué, V., and Van Velthoven, P.: Updated African biomass burning emission inventories in the framework of the AMMA-IDAF program, with an evaluation of combustion aerosols, Atmos. Chem. Phys., 10, 9631-9646, https://doi.org/10.5194/acp-10-9631-2010, 2010.

Liousse, C., Assamoi, E., Criqui, P., Granier, C., and Rosset, R.: Explosive growth in African combustion emissions from 2005 to 2030, Environ. Res. Lett., 9, 035003, https://doi.org/10.1088/1748-9326/9/3/035003, 2014.

Lonati, G., Ozgen, S., and Giugliano, M.: Primary and secondary carbonaceous species in $\mathrm{PM}_{2.5}$ samples in Milan (Italy), Atmos. Environ., 41, 4599-4610, https://doi.org/10.1016/j.atmosenv.2007.03.046, 2007.

Mallet, M., Pont, V., Liousse, C., Gomes, L., Pelon, J., Osborne, S., Haywood, J., Roger, J.-C., Dubuisson, P., and Mariscal, A.: Aerosol direct radiative forcing over Djougou (northern Benin) during the African Monsoon Multidisciplinary Analysis Dry Season Experiment (Special Observation Period-0), J. Geophys. Res.-Atmos., 113, D00C01, https://doi.org/10.1029/2007JD009419, 2008.

Mama, D., Dimon, B., Aina, M., Adounkpe, J., Ahomadegbe, M., Youssao, A., Kouazounde, J., Kouanda, S. P., and Moudachirou, M.: Transport urbain au Benin et pollution atmosphérique: évaluation quantitative de certains polluants chimiques de Cotonou, Int. J. Biol. Chem. Sci., 7, 377-386, 2013.

Meng, Z., Jiang, X., Yan, P., Lin, W., Zhang, H., and Wang, Y.: Characteristics and sources of $\mathrm{PM}_{2.5}$ and carbonaceous species during winter in Taiyuan, China, Atmos. Environ., 41, 69016908, 2007.

Mkoma, S. L., Kawamura, K., and Fu, P. Q.: Contributions of biomass/biofuel burning to organic aerosols and particulate matter in Tanzania, East Africa, based on analyses of ionic species, organic and elemental carbon, levoglucosan and mannosan, Atmos. Chem. Phys., 13, 10325-10338, https://doi.org/10.5194/acp-13-10325-2013, 2013.

Mmari, A. G., Potgieter-Vermaak, S. S., Bencs, L., McCrindle, R. I., and Van Grieken, R.: Elemental and ionic components of atmospheric aerosols and associated gaseous pollutants in and near Dar es Salaam, Tanzania, Atmos. Environ., 77, 51-61, https://doi.org/10.1016/j.atmosenv.2013.04.061, 2013. 
Naidja, L., Ali-Khodja, H., and Khardi, S.: Particulate matter from road traffic in Africa, J. Earth Sci. Geotech. Eng., 7, 389-304, 2017.

O’Neill, N. T., Eck, T. F., Smirnov, A., Holben, B. N., and Thulasiraman, S.: Spectral discrimination of coarse and fine mode optical depth, J. Geophys. Res.-Atmos., 108, 4559, https://doi.org/10.1029/2002JD002975, 2003.

Ouafo-Leumbe, M.-R., Galy-Lacaux, C., Liousse, C., Pont, V., Akpo, A., Doumbia, T., Gardrat, E., Zouiten, C., SighaNkamdjou, L., and Ekodeck, G. E.: Chemical composition and sources of atmospheric aerosols at Djougou (Benin), Meteorol. Atmos. Phys., 1-19, https://doi.org/10.1007/s00703-017-0538-5, 2017.

Pachauri, T., Singla, V., Satsangi, A., Lakhani, A., and $\mathrm{Ku}-$ mari, K. M.: Characterization of carbonaceous aerosols with special reference to episodic events at Agra, India, Atmos. Res., 128, 98-110, https://doi.org/10.1016/j.atmosres.2013.03.010, 2013.

Parker, D. J. and Diop-Kane, M.: Meteorology of Tropical West Africa: The Forecasters' Handbook, John Wiley \& Sons, Chichester, UK, 2017.

Porter, J. N., Miller, M., Pietras, C., and Motell, C.: Ship-based sun photometer measurements using Microtops sun photometers, J. Atmos. Ocean. Tech., 18, 765-774, https://doi.org/10.1175/15200426(2001)018<0765:SBSPMU>2.0.CO;2, 2001.

Querol, X., Alastuey, A., Ruiz, C. R., Artiñano, B., Hansson, H. C., Harrison, R. M., Buringh, E., ten Brink, H. M., Lutz, M., Bruckmann, P., Straehl, P., and Schneider, J.: Speciation and origin of $\mathrm{PM}_{10}$ and PM2.5 in selected European cities, Atmos. Environ., 38, 6547-6555, https://doi.org/10.1016/j.atmosenv.2004.08.037, 2004.

Remer, L. A., Kleidman, R. G., Levy, R. C., Kaufman, Y. J., Tanré, D., Mattoo, S., Martins, J. V., Ichoku, C., Koren, I., and $\mathrm{Yu}, \mathrm{H}$.: Global aerosol climatology from the MODIS satellite sensors, J. Geophys. Res.-Atmos., 113, D14S07, https://doi.org/10.1029/2007JD009661, 2008.

Roy, D. P. and Boschetti, L.: Southern Africa validation of the MODIS, L3JRC, and GlobCarbon burnedarea products, IEEE T. Geosci. Remote, 47, 1032-1044, https://doi.org/10.1109/TGRS.2008.2009000, 2009.

Roy, D. P., Boschetti, L., Justice, C. O., and Ju, J.: The collection 5 MODIS burned area product - global evaluation by comparison with the MODIS active fire product, Remote Sens. Environ., 112, 3690-3707, https://doi.org/10.1016/j.rse.2008.05.013, 2008.

Sauvage, B., Thouret, V., Cammas, J.-P., Gheusi, F., Athier, G., and Nédélec, P.: Tropospheric ozone over Equatorial Africa: regional aspects from the MOZAIC data, Atmos. Chem. Phys., 5, 311335, https://doi.org/10.5194/acp-5-311-2005, 2005.

Schmid, B. and Wehrli, C.: Comparison of Sun photometer calibration by use of the Langley technique and the standard lamp, Appl. Optics, 34, 4500, https://doi.org/10.1364/AO.34.004500, 1995.

Shen, G., Xue, M., Wei, S., Chen, Y., Zhao, Q., Li, B., Wu, H., and Tao, S.: Influence of fuel moisture, charge size, feeding rate and air ventilation conditions on the emissions of PM, OC, EC, parent PAHs, and their derivatives from residential wood combustion, J. Environ. Sci., 25, 1808-1816, 2013.

Shi, Y., Ji, Y., Sun, H., Hui, F., Hu, J., Wu, Y., Fang, J., Lin, H., Wang, J., Duan, H., and Lanza, M.: Nanoscale characterization of $\mathrm{PM}_{2.5}$ airborne pollutants reveals high adhesiveness and ag- gregation capability of soot particles, Sci. Rep.-UK, 5, 11232 , https://doi.org/10.1038/srep11232, 2015.

Smirnov, A., Holben, B. N., Eck, T. F., Dubovik, O., and Slutsker, I.: Cloud-screening and quality control algorithms for the AERONET database, Remote Sens. Environ., 73, 337-349, 2000.

Smirnov, A., Holben, B. N., Eck, T. F., Slutsker, I., Chatenet, B., and Pinker, R. T.: Diurnal variability of aerosol optical depth observed at AERONET (Aerosol Robotic Network) sites, Geophys. Res. Lett., 29, 30-1-30-4, https://doi.org/10.1029/2002GL016305, 2002.

Soufflet, V., Devaux, C., and Tanré, D.: Modified Langley Plot Method for measuring the spectral aerosol optical thickness and its daily variations, Appl. Optics, 31, 2154, https://doi.org/10.1364/AO.31.002154, 1992.

Sultan, B. and Janicot, S.: The West African monsoon dynamics. Part II: The "preonset" and "onset" of the summer monsoon, J. Climate, 16, 3407-3427, https://doi.org/10.1175/15200442(2003)016<3407:TWAMDP>2.0.CO;2, 2003.

Tahri, M., Bounakhla, M., Zghaïd, M., Noack, Y., Benyaïch, F., and Benchrif, A.: Evaluation of airborne particulate matter pollution in Kenitra City Morocco, Rev. Ambiente Água, 8, 38-47, 2013.

Terrouche, A., Ali-Khodja, H., Kemmouche, A., Bouziane, M., Derradji, A., and Charron, A.: Identification of sources of atmospheric particulate matter and trace metals in Constantine, Algeria, Air Qual. Atmos. Hlth., 9, 69-82, https://doi.org/10.1007/s11869-014-0308-1, 2016.

Toledano, C., Cachorro, V. E., Berjon, A., De Frutos, A. M., Sorribas, M., De la Morena, B. A., and Goloub, P.: Aerosol optical depth and Ångström exponent climatology at El Arenosillo AERONET site (Huelva, Spain), Q. J. Roy. Meteor. Soc., 133, 795-807, 2007.

Tripti, P., Saraswat, R. K., Singla, V., Lakhani, A., and Kumari Maharaj, K.: Characterization of organic and elemental carbon in $\mathrm{PM}_{2.5}$ aerosols at Agra, India, Research Journal of Recent Sciences, 2013.

Turpin, B. J. and Huntzicker, J. J.: Secondary formation of organic aerosol in the Los Angeles Basin: a descriptive analysis of organic and elemental carbon concentrations, Atmos. Environ. A Gen., 25, 207-215, https://doi.org/10.1016/09601686(91)90291-E, 1991.

Turpin, B. J. and Huntzicker, J. J.: Identification of secondary organic aerosol episodes and quantitation of primary and secondary organic aerosol concentrations during SCAQS, Atmos. Environ., 29, 3527-3544, 1995.

UNEP: available at: https://environmentlive.unep.org/publication/ country/C\%C3\%B4te\%20d' Ivoire/unep (last access: 23 April 2018), 2015.

Val, S., Liousse, C., Doumbia, E. H. T., Galy-Lacaux, C., Cachier, H., Marchand, N., Badel, A., Gardrat, E., Sylvestre, A., and Baeza-Squiban, A.: Physico-chemical characterization of African urban aerosols (Bamako in Mali and Dakar in Senegal) and their toxic effects in human bronchial epithelial cells: description of a worrying situation, Part. Fibre Toxicol., 10, 10, https://doi.org/10.1186/1743-8977-10-10, 2013.

van Donkelaar, A., Martin, R. V., Brauer, M., Kahn, R., Levy, R., Verduzco, C., and Villeneuve, P. J.: Global estimates of ambient fine particulate matter concentrations from satellite-based aerosol optical depth: development 
and application, Environ. Health Persp., 118, 847-855, https://doi.org/10.1289/ehp.0901623, 2010.

Verma, S., Prakash, D., Ricaud, P., Payra, S., Attié, J.-L., and Soni, M.: A new classification of aerosol sources and types as measured over Jaipur, India, Aerosol Air Qual. Res., 15, 985993, 2015.

Viidanoja, J., Sillanpää, M., Laakia, J., Kerminen, V.-M., Hillamo, R., Aarnio, P., and Koskentalo, T.: Organic and black carbon in $\mathrm{PM}_{2.5}$ and $\mathrm{PM}_{10}$ : 1 year of data from an urban site in Helsinki, Finland, available at: http://www.sciencedirect.com/science/ article/pii/S1352231002002054 (last access: 24 May 2017), 2002.

Volz, F.: Photometer mit Selen-Photoelement zur spektralen Messung der Sonnenstrahlung und zur Bestimmung der Wellenlängenabhängigkeit der Dunsttrübung, Arch. Meteor. Geophy. B, 10, 100-131, https://doi.org/10.1007/BF02243122, 1959.

Volz, F. E.: Economical multispectral sun photometer for measurements of aerosol extinction from $0.44 \mu \mathrm{m}$ to $1.6 \mu \mathrm{m}$ and precipitable water, Appl. Optics, 13, 1732-1733, https://doi.org/10.1364/AO.13.001732, 1974.

Wang, J.: Intercomparison between satellite-derived aerosol optical thickness and $\mathrm{PM}_{2.5}$ mass: implications for air quality studies, Geophys. Res. Lett., 30, 2095, https://doi.org/10.1029/2003GL018174, 2003.

West, J. J., Cohen, A., Dentener, F., Brunekreef, B., Zhu, T., Armstrong, B., Bell, M. L., Brauer, M., Carmichael, G., Costa, D. L., Dockery, D. W., Kleeman, M., Krzyzanowski, M., Künzli, N., Liousse, C., Lung, S.-C. C., Martin, R. V., Pöschl, U., Pope, C. A., Roberts, J. M., Russell, A. G. and Wiedinmyer, C.: What we breathe impacts our health: improving understanding of the link between air pollution and health, Environ. Sci. Technol., 50, 4895-4904, https://doi.org/10.1021/acs.est.5b03827, 2016.

Zakey, A. S., Abdel-Wahab, M. M., Pettersson, J. C., Gatari, M. J., and Hallquist, M.: Seasonal and spatial variation of atmospheric particulate matter in a developing megacity, the Greater Cairo, Egypt, Atmósfera, 21, 171-189, 2008.
Zghaid, M., Noack, Y., Bounakla, M., and Benyaich, F.: Pollution atmosphérique particulaire dans la ville de Kenitra (Maroc), available at: http://lodel.irevues.inist.fr/ pollution-atmospherique/index.php?id=1184\&format=print (last access: 24 May 2017), 2009.

Zhang, F., Zhao, J., Chen, J., Xu, Y., and Xu, L.: Pollution characteristics of organic and elemental carbon in $\mathrm{PM}_{2.5}$ in Xiamen, China, J. Environ. Sci., 23, 1342-1349, https://doi.org/10.1016/S1001-0742(10)60559-1, 2011.

Zhang, L., Huang, Y., Liu, Y., Yang, F., Lan, G., Fu, C., and Wang, J.: Characteristics of carbonaceous species in $\mathrm{PM}_{2.5}$ in Wanzhou in the Hinterland of the Three Gorges Reservior of Northeast Chongqing, China, Atmosphere, 6, 534-546, https://doi.org/10.3390/atmos6040534, 2015.

Zhang, Q., Jimenez, J. L., Canagaratna, M. R., Allan, J. D., Coe, H., Ulbrich, I., Alfarra, M. R., Takami, A., Middlebrook, A. M., Sun, Y. L., Dzepina, K., Dunlea, E., Docherty, K., DeCarlo, P. F., Salcedo, D., Onasch, T., Jayne, J. T., Miyoshi, T., Shimono, A., Hatakeyama, S., Takegawa, N., Kondo, Y., Schneider, J., Drewnick, F., Borrmann, S., Weimer, S., Demerjian, K., Williams, P., Bower, K., Bahreini, R., Cottrell, L., Griffin, R. J., Rautiainen, J., Sun, J. Y., Zhang, Y. M., and Worsnop, D. R.: Ubiquity and dominance of oxygenated species in organic aerosols in anthropogenically-influenced Northern Hemisphere midlatitudes, Geophys. Res. Lett., 34, https://doi.org/10.1029/2007GL029979, 2007.

Zhou, M., Wang, R., Mai, S., and Tian, J.: Spatial and temporal patterns of air quality in the three economic zones of China, J. Maps, 12, 156-162, https://doi.org/10.1080/17445647.2016.1187095, 2016. 